\title{
Carbon cycle in tropical upland ecosystems: a global review
}

\author{
Dennis Castillo-Figueroa \\ Biology Department, Faculty of Natural Sciences, Universidad del Rosario, Bogotá, 111321, Colombia \\ Correspondence: Dennis Castillo-Figueroa (dennis.castillo@urosario.edu.co)
}

Received: 16 June 2021 - Revised: 8 November 2021 - Accepted: 10 November 2021 - Published: 8 December 2021

\begin{abstract}
Along with habitat transformation, climate change has profound impacts on biodiversity and may alter ecosystem services on which human welfare depends. Many studies of the carbon cycle have focused on lowland tropical forests; however, upland forests have been less explored despite their pivotal role in carbon sequestration. Here, I synthesized the state of knowledge on the allocation of carbon in its different stocks (aboveground, belowground, and soil) as well as in its main fluxes (plant decomposition, respiration, and litterfall) in tropical upland ecosystems of the planet. In November 2020, a systematic review was carried out to identify references published from 2000 to 2020 through a combination of key terms in Google Scholar and Scopus databases, thus analysing bibliographic, geographical, methodological, and carbon cycling information of the global upland tropics (between $23.5^{\circ} \mathrm{N}-23.5^{\circ} \mathrm{S}$ ). After analysing a total of 1967 references according to inclusion-exclusion criteria, 135 references published in the last 20 years were selected. Most of the studies were conducted in the tropical and subtropical moist broadleaf forest of South America. The main factors studied were elevation and forest type. Forest structure and soil variables were largely associated when studying carbon cycling in these ecosystems. Estimations of carbon stocks comprised three-fourths of the total studies, while the remaining fraction focused on carbon fluxes. Aboveground biomass and carbon in soils were highly investigated, while plant decomposition and respiration were the components that received the least attention. Even though in the last 20 years there was a slight increase in the number of studies on carbon cycle in tropical upland forests, I found bias associated with the biomes and ecoregions studied (especially in the Andes). Elevation was the main factor examined but other essential aspects such as the successional gradient, landscape management, diversityproductivity relationship, faunal and microbial effect, trophic cascades, and Gadgil effect require more attention. The inclusion of different litter species and origins (i.e. roots and stems) and theoretical frameworks including home-field advantage, substrate-matrix interaction, and phenology-substrate match may provide explanatory mechanisms to better understand litter decomposition over these forests. Despite respiration being a paramount link that is closely tied to above- and belowground compartment, this flux constitutes one of the important gaps to fulfil in future research. For a comprehensive understanding of the carbon cycle in upland forests, it is necessary to obtain information on its main fluxes and integrate them into climate change mitigation plans.
\end{abstract}

\section{Introduction}

Climate change is one of the major socio-environmental concerns worldwide (IPCC, 2014; Cuervo-Robayo et al., 2020). Global changes in mean atmospheric temperature and rainfall have changed dramatically over the last 140 years with increases up to $0.95^{\circ} \mathrm{C}$, as well as extreme precipitation and drought events (NOAA, 2021). Altogether with habitat transformation, climate change can cause profound impacts on biodiversity and, consequently, may disrupt ecosystem processes and services on which human well-being depends (Sala et al., 2000; Loreau et al., 2001) such as food, fibre, and wood production (Beer et al., 2010). Therefore, quantifying carbon sequestration in each of its compartments as well as its main fluxes is critical for designing effective policies that are intended to reduce greenhouse emissions and 
mitigate climate change, especially in developing countries (de la Cruz-Amo et al., 2020).

Tropical forests play a key role in carbon sequestration since they account for a quarter of global carbon storage (Bonan, 2008; Poorter et al., 2015) and a third of terrestrial net primary production (NPP) (Beer et al., 2010; Poorter et al., 2015). Within tropical forests, mountain regions represent a significant proportion of the world's biodiversity. Indeed, despite the relatively small area in mountain forests (ca. $25 \%$ land surface of the Earth) (Körner, 2007), this region hosts $87 \%$ of Earth's species of amphibians, birds, and mammals, many of which are entirely restricted to tropical mountains (Rahbek et al., 2019). In particular, tropical upper montane ecosystems are highly idiosyncratic because of their ecological and evolutionary singularities, which are very different from the lowland tropics (Malhi et al., 2010). Beyond constituting an upslope extension of lowlands, tropical upland forests are characterized by extraordinary local endemism and high rates of beta-diversity (Olson and Dinerstein, 2002; Calbi et al., 2021; Hurtado-Martilleti et al., 2021), which are mainly explained by the topographic heterogeneity (Pierick et al., 2021), the broad range of climatic environments (Malhi et al., 2010), and the complex geophysical structures (Körner, 2007; Körner and Spehn, 2019). These characteristics, at the same time, hinder mountain research, and many ecological questions remains to be answered, especially in ecosystem functioning. In fact, fundamental processes such as the carbon cycle are understudied in comparison to lowland tropical forests, which has received more attention (Malhi et al., 2010; Rubiano et al., 2017). Furthermore, the role of land use in the conservation status and carbon storage of these ecosystems as well as the interactions between climate change and land use change add an extra layer of complexity that is still not fully understood. Considering the importance of tropical mountain forests to climate change (Duque et al., 2021; Bendix et al., 2021), improving our understanding of the carbon cycle is critical to evaluate potential climate change impacts on natural resources from this region and, in this way, to further implement adaptation strategies to global warming.

It has been estimated that biotic carbon allocated into terrestrial plants counts for about $80 \%$ of all taxa on Earth $(450 \mathrm{GtC})$, from which $320 \mathrm{GtC}$ is bound to aboveground biomass, mainly in stems and tree trunks, and $130 \mathrm{GtC}$ is accumulated in plant roots (Bar-On et al., 2018). Moreover, belowground biomass including microorganisms residing in the soil is also an important stock, especially along highland forests (de la Cruz-Amo et al., 2020). Despite some studies have quantified carbon stocks in tropical mountain forests by using several approaches including allometric equations (Phillips et al., 2019; Asrat et al., 2020; Calderón-Loor et al., 2020), fine root biomass in soil cores (Moser et al., 2011; Werner and Homeier, 2015), and carbon in soil pits (Wilcke et al., 2008; Zimmermann et al., 2010a), the estimation of carbon allocation is not clear or comprehensive, and the information about carbon stocks remains sparse, contrary to lowland ecosystems (e.g., grasslands, Amazonian basin). Also, the analysis of the fluxes is generally excluded when scrutinizing carbon cycling in spite of being essential to establish the relationships between above- and belowground compartments.

Gathering information about how carbon is allocated aboveground, belowground, and in the soil organic matter, also how it is recycled in its principal fluxes, can be useful to evaluate the progress in the study of the carbon cycle in the tropical upland region. This way, it is possible to identify knowledge gaps and define future research avenues in these ecosystems within the context of climate change. Therefore, the objective of this systematic review was to synthesize the state of knowledge of the allocation of carbon stocks in its different compartments (i.e. aboveground biomass, belowground biomass, and soil organic matter) and its main fluxes (i.e. plant decomposition, respiration, and litterfall) in tropical upland ecosystems. I discuss the general patterns of bibliographic, geographical, methodological, and carbon cycle information identified in the contents of the scientific studies found in this review.

\section{Methods}

\subsection{Data searching}

On 1 November 2020, I conducted an extensive review through the academic databases of Google and Scopus, searching for the available scientific literature from 2000 to 2020 that contained in the title, abstract, and/or keywords the following search terms with all the possible combinations: ("Carbon stock" or "Aboveground biomass" or "Net primary production" or "Productivity" or "Fine root biomass" or "Belowground biomass" or "Litterfall" or "Soil organic carbon" or "Soil respiration" or "Litter decomposition" or "Carbon cycle") and ("Mountain forests" or "Montane ecosystems") and ("Tropics").

It is worth mentioning the limitation of search terms, considering the stringent key words used, as the objective of this systematic review was to evaluate the upland ecosystems only. In particular, the selection of the terms "Mountain forests" and "Montane ecosystems" provides a useful combination of words to obtain a wide range of studies carried out on mountain ecosystems. This was done with the intention of including all the possible studies carried out in the uplands since many of them could be part of investigations that assess altitudinal transects from lowland to upland mountain ecosystems. However, a literature search with more flexible key terms and considering the elevation as the only criteria to select upland ecosystems could provide a higher number of studies (see inclusion criteria), rather than the more restricted but direct and ecological criteria that this review attempts to address. 


\subsection{Inclusion-exclusion criteria}

After removing duplicate documents and grey literature (e.g. theses, conference proceedings, and technical reports), I evaluated a total of 1967 references retrieved by Google scholar and Scopus according to the following inclusion criteria by reviewing the title, keywords, and abstract: (1) the forests were located in the tropics $\left(23.5^{\circ} \mathrm{N}\right.$ and $\left.23.5^{\circ} \mathrm{S}\right)$, and (2) the study focused on at least one of the allocation components (aboveground biomass, belowground biomass, soil organic carbon) or carbon fluxes (decomposition rates, respiration, litterfall). This reduced the results to 564 references. Posteriorly, I excluded the references in which the analysed ecosystems belonged to the "Lowlands" according to the bioclimatic belts proposed by Körner et al. (2011). That is, thermal belts of "Remaining mountain area with frost" and "Remaining mountain area without frost" were excluded. This way, upland ecosystems examined in the selected studies pertained to the thermal belts of "Upper montane", "Lower montane", "Lower alpine", and "Upper alpine" (Körner et al., 2011), thus removing 429 references from the 564 previously included (Fig. A1). To do this, I used the Global Mountain Explorer platform (https://rmgsc.cr.usgs.gov/gme/gme. shtml, last access: 12 March 2021) for assigning the thermal belt to each study site. Despite tropical montane forests having been defined as ecosystems between $23.5^{\circ} \mathrm{N}$ and $23.5^{\circ} \mathrm{S}$ above $1000 \mathrm{~m}$ elevation (Spracklen and Righelato, 2014), montane belts based on temperature seem to be a better ecological criterion than altitude itself (Körner, 2007; Körner et al., 2011; Körner and Sphen, 2019), because altitude represents an indirect variable and an arbitrary measure of the zonation of mountain forests that can be confounded with several local and regional characteristics such as the inclination and direction of slopes, architecture of plants, drought, or even land use, among others (Körner, 2007).

\subsection{Data analysis}

The selected references were organized in Microsoft Excel 2016 using mainly crosstabs. From each document, the information was collected according to bibliographic, geographical, methodological, and carbon cycling information as described in Table 1. To analyse co-occurrence of key words from all the studies, VOSviewer 1.6.16 was employed.

When an article covered different characteristics (e.g. different topics, factors, components, variables), each characteristic was accounted for independently. Based on the description and coordinates of study areas for each document, biomes and ecoregions were obtained according to the platform Ecoregions 2017 (c) Resolve (https://ecoregions2017. appspot.com/, last access: 24 February 2021) (Olson et al., 2001; Dinerstein et al., 2017). The percentage of publications of each function was quantified with a respective number of studies $(n)$.

\section{Results}

\subsection{Bibliographic information}

The search in Scopus yielded 987 results while in Google Scholar 980 results were found, which were reviewed entirely, thus obtaining a total of 135 documents that coincide with the inclusion-exclusion criteria described in the methodology (Fig. A1 and Table B1). Four clusters were identified in co-occurrence of keywords as is depicted in Fig. 1. The number of publications showed a slightly positive but not significant trend in the 20 years analysed ( $p=0.121$; $R^{2}=0.12 ; n=135$; Fig. $\left.2 \mathrm{a}\right)$, especially after the end of the first decade of the 2000s. The studies were published in 64 peer-reviewed scientific journals (Table B1). The journals with the highest number of studies were Journal of Tropical Ecology $(n=8)$, Forest Ecology and Management $(n=8)$, and Global Change Biology $(n=6)$.

The main topics on which these investigations were developed included elevational gradients $(n=82)$, carbon balance and estimation $(n=76)$, and soil properties $(n=51)$, while the least investigated topics were related to studies of landscape ecology $(n=1)$, functional diversity $(n=3)$, and landslides and erosion $(n=2)$ (Fig. 2b). Regarding the type of study, empirical investigations focused on the estimation of aboveground biomass were of high research interest ( $n=93)$, followed by experimental studies that calculated mostly belowground biomass and leaf-litter decomposition $(n=19)$. In a sharp contrast, syntheses $(n=3)$ and metaanalyses $(n=2)$ were uncommon (Fig. 2c). In line with this, most of the studies were original articles $(n=127)$ while short communications $(n=1)$ and review papers $(n=2)$ were scarce (Fig. 2d).

\subsection{Spatial information}

The country where more research on carbon cycle was carried out was Ecuador $(n=47)$, followed by Peru $(n=28)$ (Fig. 3a). Tropical and subtropical moist broadleaf forest was the biome where most studies were conducted $(n=$ $115)$, while montane grasslands and shrublands were the second ones with more investigations $(n=43)$ (Fig. 3a). The vast majority of studies were concentrated in three biogeographic realms: Neotropics $(n=97)$, Afrotropics $(n=13)$, and Oceania ( $n=11$ ) (Fig. 3b). This is mirrored in different ecoregions such as the Eastern Cordillera Real Montane Forest $(n=39)$, Peruvian Yungas $(n=23)$, and Central Andean Wet Puna ( $n=16$ ) (Fig. 3b). In terms of bioclimatic belts, the lower montane belt was the thermal life zone where the most studies took place $(n=106)$, while the upper montane $(n=39)$ and lower alpine belts $(n=11)$ were the least studied. 
Table 1. General description of the components identified in the individual assessment of the article contents.

\begin{tabular}{|c|c|c|}
\hline Component assessed & Variable analysed & Description \\
\hline \multirow[t]{5}{*}{ Bibliographic information } & Year & $\begin{array}{l}\text { When was the study } \\
\text { published? }\end{array}$ \\
\hline & Type of publication & $\begin{array}{l}\text { What was the format of the } \\
\text { study? }\end{array}$ \\
\hline & Study type & $\begin{array}{l}\text { What was the nature of the } \\
\text { study? }\end{array}$ \\
\hline & Journal & $\begin{array}{l}\text { In what journal was the study } \\
\text { published? }\end{array}$ \\
\hline & $\begin{array}{l}\text { Disciplinary subject of the } \\
\text { study }\end{array}$ & $\begin{array}{l}\text { What was the framework of the } \\
\text { study? }\end{array}$ \\
\hline \multirow[t]{6}{*}{ Geographical information } & Site (country and city) & $\begin{array}{l}\text { In what country was the study } \\
\text { conducted? }\end{array}$ \\
\hline & Altitude & $\begin{array}{l}\text { In what altitudinal range was } \\
\text { the study conducted? }\end{array}$ \\
\hline & Realm & $\begin{array}{l}\text { In what realm was the study } \\
\text { conducted? }^{\mathrm{a}}\end{array}$ \\
\hline & Biome & $\begin{array}{l}\text { In what biome was the study } \\
\text { conducted? }^{\mathrm{a}}\end{array}$ \\
\hline & Ecoregion & $\begin{array}{l}\text { In what ecoregion was the } \\
\text { study conducted? }^{\text {a }}\end{array}$ \\
\hline & Mountain belt & $\begin{array}{l}\text { In what mountain belt was the } \\
\text { study conducted? }^{\text {b }}\end{array}$ \\
\hline \multirow[t]{3}{*}{ Methodological information } & Variables analysed & $\begin{array}{l}\text { Which were the } \\
\text { complementary variables } \\
\text { analysed? Biotic (e.g. } \\
\text { diversity, composition), } \\
\text { climate (e.g. temperature, } \\
\text { humidity, precipitation), } \\
\text { soil (e.g. physicochemical } \\
\text { properties), functional traits } \\
\text { (e.g. foliar traits), forest } \\
\text { structure (e.g. diameter at } \\
\text { breast height, basal area), } \\
\text { topography (slope), landscape } \\
\text { (e.g. size, distribution). }\end{array}$ \\
\hline & Factors evaluated & $\begin{array}{l}\text { Which were the factors tested } \\
\text { in the study? (e.g. elevation, } \\
\text { time, landscape management, } \\
\text { seasonality). }\end{array}$ \\
\hline & Methods for carbon assessment & $\begin{array}{l}\text { Which methods were } \\
\text { employed to estimate carbon } \\
\text { stocks and/or fluxes? Stocks } \\
\text { (i.e. aboveground, } \\
\text { belowground, and soil) and } \\
\text { fluxes (i.e. plant } \\
\text { decomposition, litterfall, } \\
\text { respiration). }\end{array}$ \\
\hline
\end{tabular}


Table 1. Continued.

\begin{tabular}{|c|c|c|}
\hline Component assessed & Variable analysed & Description \\
\hline \multirow[t]{4}{*}{ Carbon cycling information } & Aspect analysed & $\begin{array}{l}\text { What was the aspect of the } \\
\text { carbon cycle analysed in the } \\
\text { study? (e.g. aboveground } \\
\text { biomass, fine root biomass, } \\
\text { root decomposition, soil } \\
\text { respiration). }\end{array}$ \\
\hline & Component analysed & $\begin{array}{l}\text { What was the component of the } \\
\text { carbon cycle analysed in the } \\
\text { study? Stocks (i.e. } \\
\text { aboveground, belowground, } \\
\text { and soil) and fluxes (i.e. plant } \\
\text { decomposition, litterfall, } \\
\text { respiration). }\end{array}$ \\
\hline & $\begin{array}{l}\text { Production fractions for each } \\
\text { compartment }\end{array}$ & $\begin{array}{l}\text { What were the specific } \\
\text { fractions estimated of the } \\
\text { above- and belowground } \\
\text { production in the study? (e.g. } \\
\text { NPP wood allocation, NPP to } \\
\text { canopy, NPP to coarse roots). }\end{array}$ \\
\hline & Production at ecosystem level & $\begin{array}{l}\text { What were the estimations of } \\
\text { production performed at the } \\
\text { ecosystem level? (e.g. carbon } \\
\text { use efficiency, ecosystem } \\
\text { respiration, net ecosystem } \\
\text { production). }\end{array}$ \\
\hline
\end{tabular}

a According to Ecoregions 2017 @ Resolve (https://ecoregions2017.appspot.com/, last access: 24 February 2021) (Olson et al., 2001; Dinerstein et al., 2017). ${ }^{\mathrm{b}}$ This was explored using Global Mountain Explorer (https://rmgsc.cr.usgs.gov/gme/gme.shtml, last access: 12 March 2021).

\subsection{Methodological information}

Within the main factors assessed, elevation $(n=54)$ and forest type $(n=31)$ were the most evaluated, while vertical stratification $(n=3)$, fertilization treatment $(n=3)$, and substrate $(n=1)$ were the least studied (Fig. 4a). Complementary variables associated with the analysis of the carbon cycle were forest structure like diameter at breast height, tree height, and basal area $(n=68)$; soil properties including physicochemical variables such as bulk density, $\mathrm{C} / \mathrm{N}$ ratio, minerals, and nutrients $(n=68)$; and climatic variables which comprise temperature, precipitation, and humidity $(n=68)$. Conversely, biotic variables such as plant diversity, soil macrofauna, and microbial biomass were less assessed $(n=22)$ (Fig. 4b).

Different methods were employed to estimate carbon stocks and/or fluxes; for the aboveground compartment, allometric equations $(n=47)$ were the most common method to assess aboveground biomass as well as the usage of dendrometers for track wood increment $(n=15)$ (Fig. 4c). Remote-sensing-based approaches $(n=6)$, direct collections of plant material $(n=3)$, and vegetation models for above- ground biomass monitoring $(n=1)$ as well as volume of wood debris for necromass estimations $(n=5)$ were little investigated. In the belowground compartment, soil cores $(n=20)$ and allometric equations $(n=8)$ were the principal methods to calculate root biomass (fine and coarse), followed by ingrowth cores $(n=7)$ and rhizotrons $(n=5)$, which were mainly used to evaluate changes in root biomass over time (Fig. 4d). Other belowground less explored estimations include mass balance method $(n=2)$ and root diameter increment $(n=1)$. For the assessment of soil carbon storage, the bulk of studies analysed soil pits with different horizons $(n=34)$, followed by small soil cores considering the organic layer in the top of the soil only $(n=22)$ and allometric equations $(n=6)$ (Fig. 4e).

In terms of carbon fluxes, the litterbag technique was by far the principal method to estimate plant decomposition $(n=19)$ (Fig. 4f) as well as litter traps for measure litterfall dynamics $(n=23)$ (Fig. 4g). Other methods less frequently employed include soil bags $(n=2)$ and the mass balance method $(n=2)$ for estimating decomposition rates, as well as quadrats from the forest floor $(n=7)$ and the line inter- 


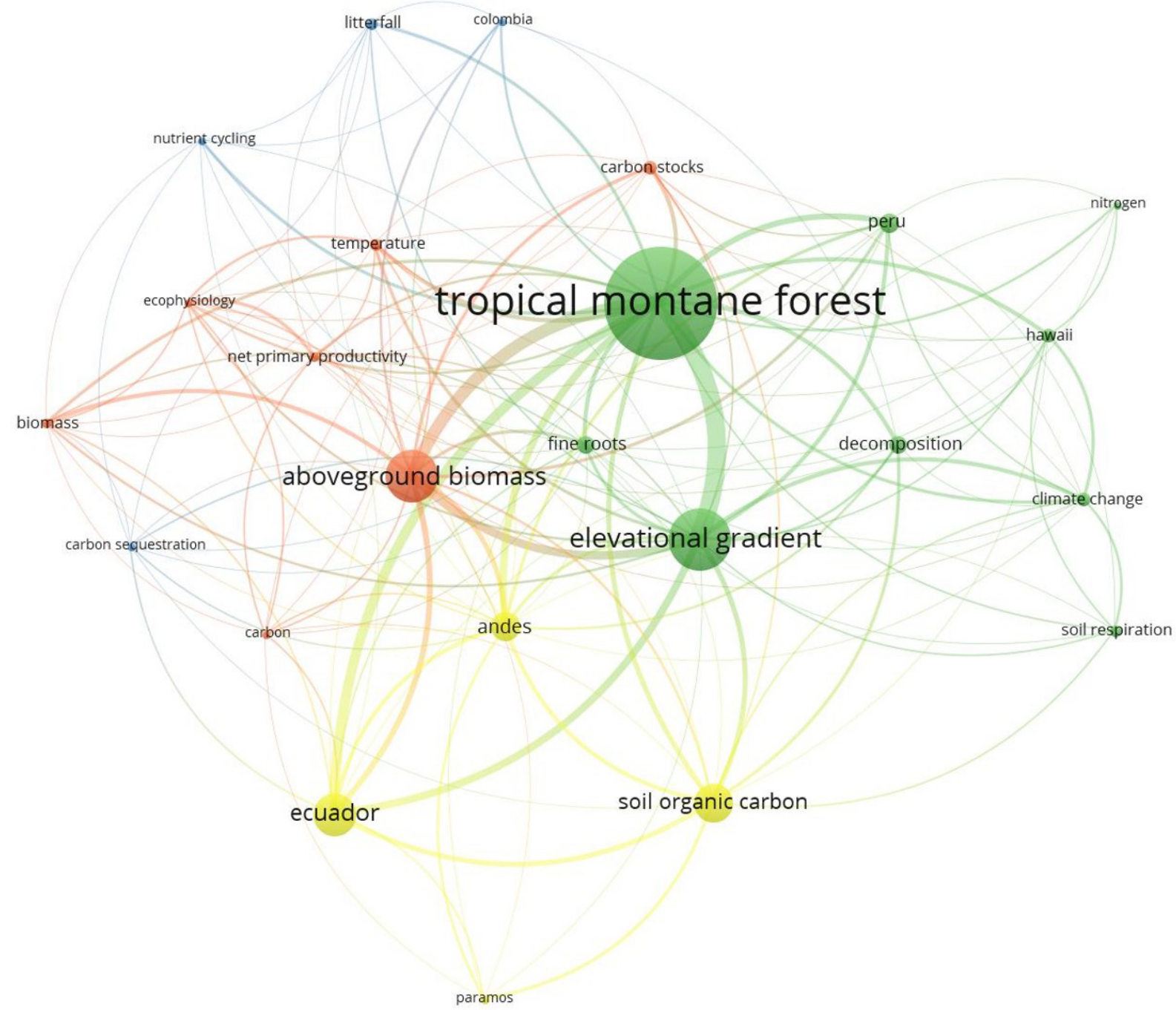

Figure 1. Analysis of the co-occurrence of keywords in publications of the carbon cycle in tropical upland ecosystems. Each colour corresponds to a different cluster. The size of each node shows the frequency of occurrence. The distance between two nodes indicates the number of co-occurrence of the two keywords; that is, the larger the distance between two nodes, the lower the co-occurrences of the two keywords. The co-occurrence in the same publication is represented by the curves between the nodes.

section method $(n=1)$ for quantify litterfall (Fig. 4f and g). Finally, $\mathrm{CO}_{2}$ fluxes from the soil, root, wood, and leaves were analysed in most of the studies by using an infra-red gas analyser (IRGA) $(n=15)$, but other methods such as substrateinduced respiration $(n=2)$, the inverted-box method $(n=$ $2)$, static chambers $(n=2)$, vegetation models $(n=1)$, and laboratory incubations $(n=1)$ were rarely used (Fig. 4h).

\subsection{Carbon cycle information}

Estimates of carbon stocks encompassed three-fourths of the total studies, while the remaining fraction focused on fluxes in the carbon cycle (Fig. 5a). Within the studies of carbon stocks, aboveground biomass $(n=69)$ and carbon in soils $(n=66)$ were the most evaluated, while within the fluxes, both respiration and plant decomposition received less attention, with 26 and 25 studies respectively (Fig. $5 \mathrm{~b}$ and c). Although litterfall was the most investigated component within the fluxes $(n=28)$, it is still understudied when compared to carbon stock estimates, since major components such as aboveground biomass and soil carbon stocks presented at least twice as many studies as for litterfall (Fig. 5b). When analysing the specific aspects assessed, for both above and belowground stocks, the necromass was little investigated along with measurements across the time (production), while for fluxes, root, wood, and microbial respiration was largely neglected combined with decomposition of roots (Fig. 5c).

Even though production estimations were little investigated for both compartments $(n=34)$, especially belowground $(n=7)$, I found 15 fractions (along with the total pro- 
(a)

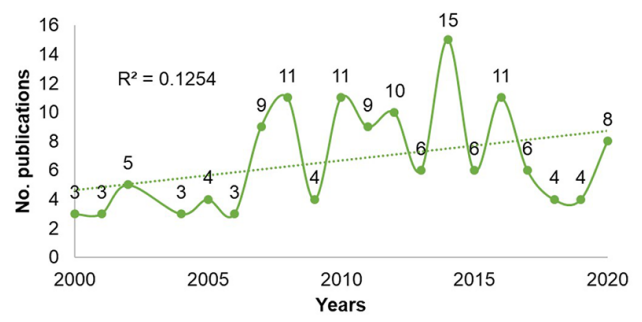

(c)

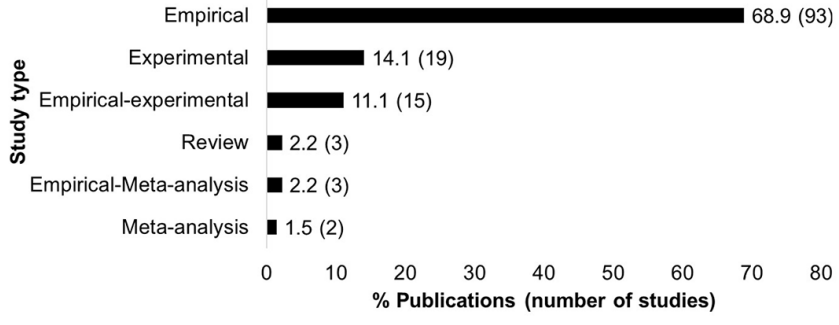

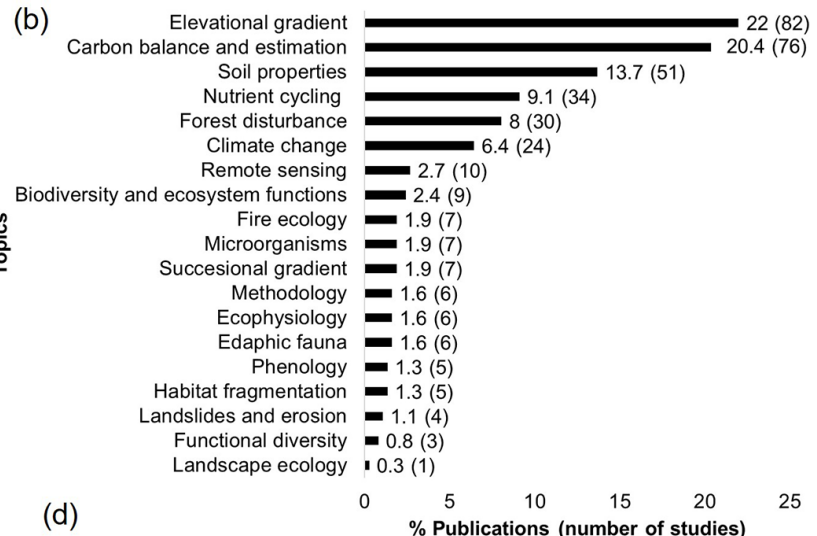

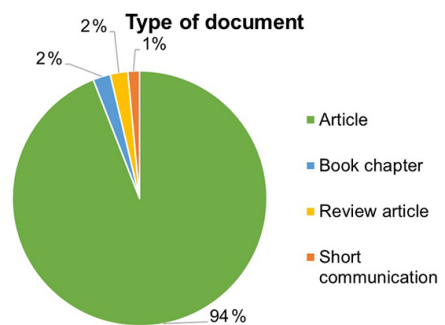

Figure 2. Bibliographic information of carbon cycle in upland tropical ecosystems. (a) Years, (b) topics, (c) type of study, and (d) type of document.

(a)

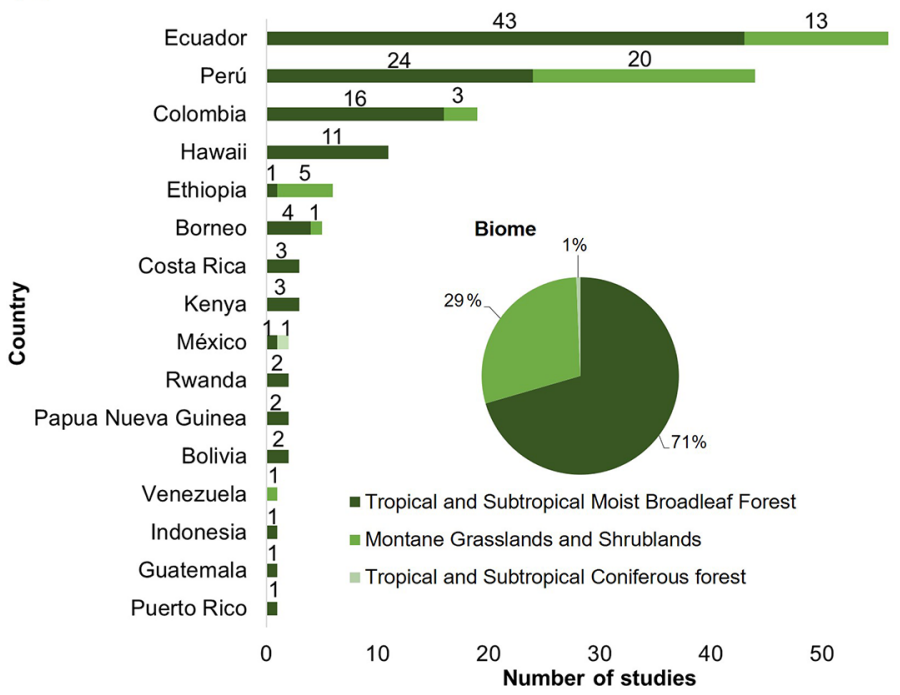

(b)

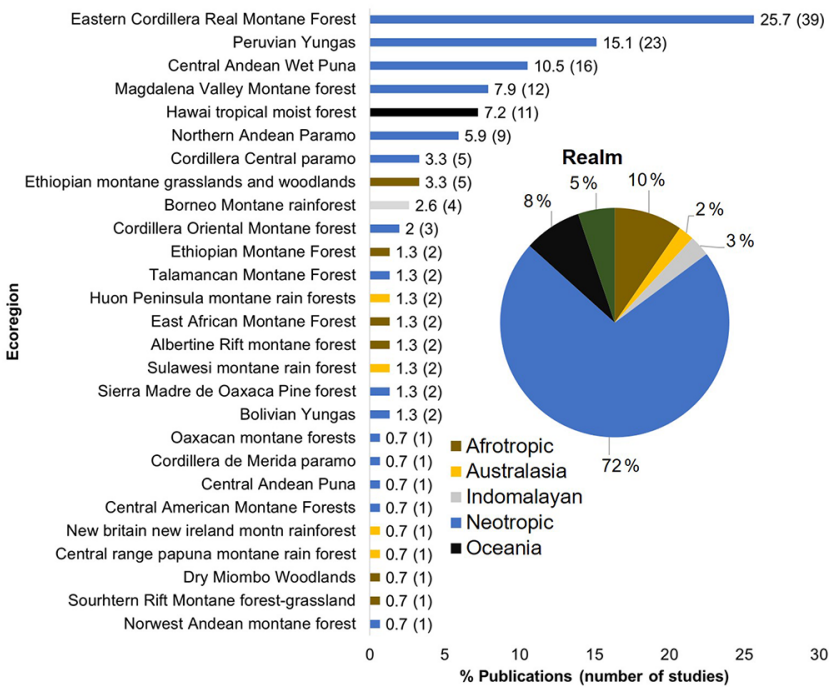

Figure 3. Geographical information from work done on the carbon cycle in tropical upland ecosystems. (a) Country and biome and (b) ecoregions and realms. The colours for each country and ecoregion indicate the evaluated biomes and realms, respectively.

duction) that were quantified for aboveground and six for belowground where stem wood increment and NPP of fine roots concentrated the highest number of studies (Fig. 6a and b). In the same way, calculations at ecosystem level of carbon production were very scarce: net ecosystem production (including both above- and belowground NPP, $n=6$ ) and carbon use efficiency $(n=4)$ were more quantified. Other ecosys- tem estimations that were rarely calculated were root / shoot ratio $(n=2)$, ecosystem respiration $(n=1)$, and NPP aboveground and NPP soil respiration $(n=1)$ (Fig. 6c). 
(a)

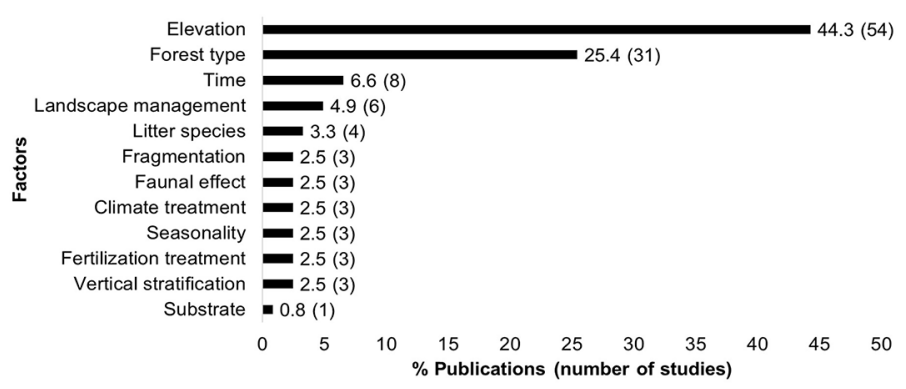

(c)
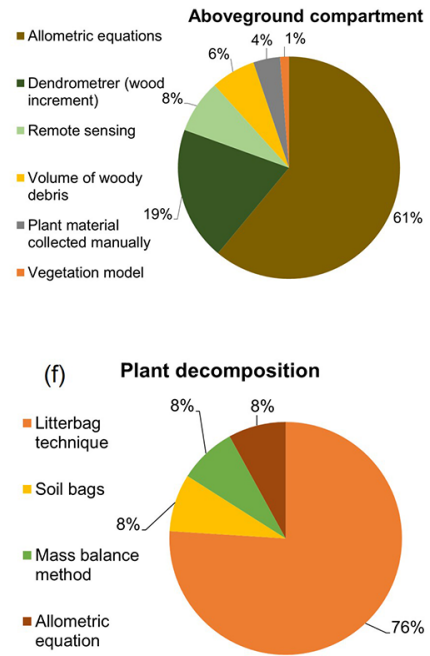

(d)

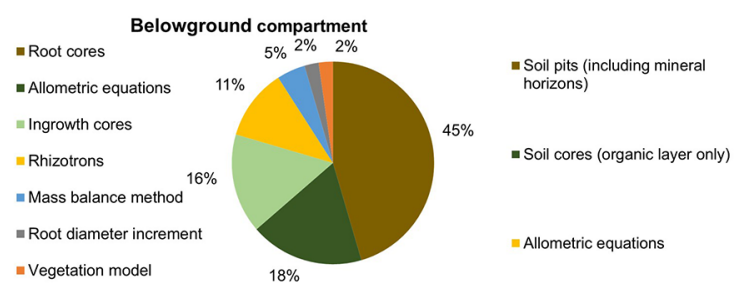

(g)

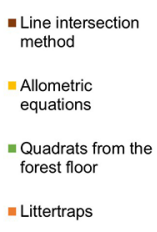

(b)

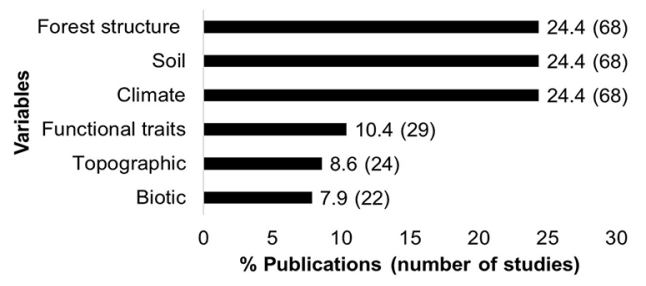

(e)

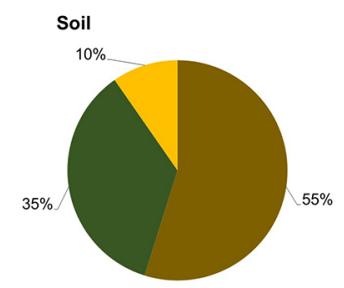

Figure 4. Methodology employed in the studies of the carbon cycle in tropical upland ecosystems. (a) Factors analysed in the studies, (b) complementary variables evaluated in the studies of the carbon cycle, (c) methods employed to quantify carbon in the aboveground compartment, (d) belowground compartment, (e) and soil organic matter. Methods used to estimate fluxes of (f) plant decomposition, (g) litterfall, and $(\mathbf{h})$ respiration.

\section{Discussion}

\subsection{General bibliographic trends}

The scientific production of the carbon cycle in the last two decades was more focused on the estimation of carbon stocks rather than on carbon fluxes. Most of the studies focused on elevational transects rather than other disturbance or successional gradients (Fig. 2b). This can be explained because altitudinal gradients have historically been explored as one of the most remarkable ecological gradients, even since the first Humboldt expeditions in the 19th century (Malhi et al., 2010; Rahbek et al., 2019).

In stark contrast, successional gradients have been studied in depth for a relatively short time (Brown and Lugo, 1990). Considering the remarkable expansion of secondary forest due to the rapid formation of human-modified landscapes in tropical mountain regions (Etter and van Wyngaarden, 2000; Rubiano et al., 2017; Hurtado-Martilleti et al.,
2021), the study of successional gradients becomes critical for understanding how carbon sequestration is affected by anthropogenic pressures. Furthermore, these kinds of studies allow us to know how the carbon sequestering potential is changed by the rate of recovery across time, which is very useful for major decision-making that promotes forest recovery in the context of climate change mitigation. In doing so, other topics which are less studied such as habitat fragmentation, landscape ecology, forest disturbance, and fire ecology can complement this research line.

One missing aspect in our understanding of the carbon cycle in upper montane ecosystems is the inclusion of ecophysiology and functional diversity, which are of substantial relevance because they provide a framework to understand the linkages between functional traits, especially the hard ones, that predict biomass gain and storage. This way it is possible to scale from the individual to ecosystem level by studying informative traits related to carbon balance such as maximum rate of photosynthesis, maximum chlorophyll flu- 


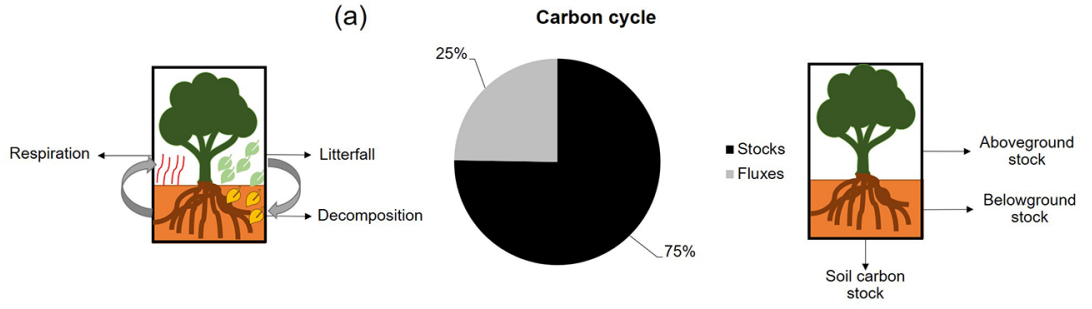

(b)

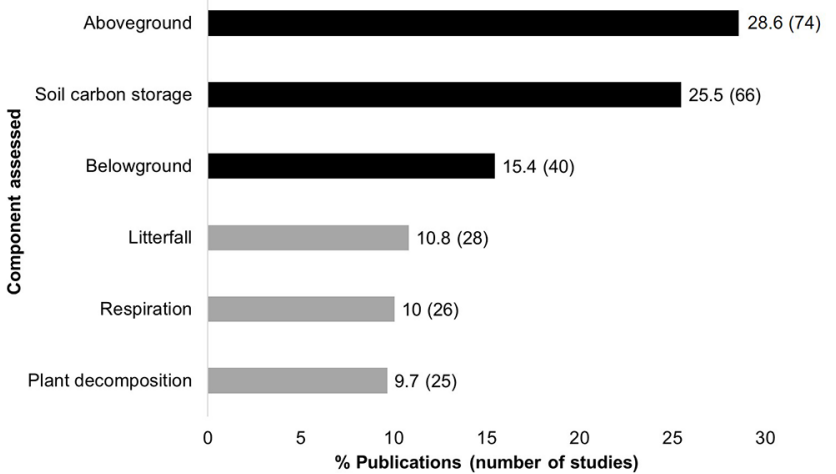

(c)

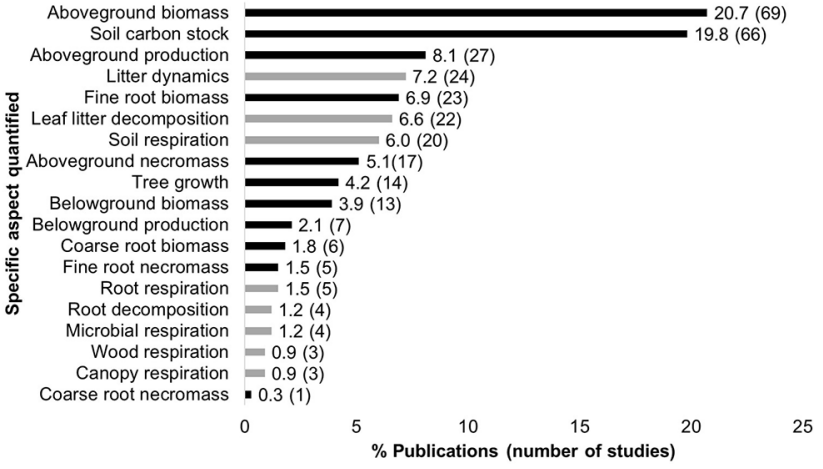

Figure 5. Information on the carbon cycle in tropical upland ecosystems. (a) Percentage of studies that estimate carbon stocks and fluxes, (b) assessed component of the carbon cycle, and (c) specific aspect quantified. The colours represent the evaluated functions (carbon stocks, fluxes).

orescence, and time to maximum photosynthesis (Rawat et al., 2015). Additionally, functional traits can also be critical for understanding the dynamics of fine roots in the carbon storage and nutrient acquisition, but this is still in its infancy (Pierick et al., 2021). Traits such as root diameter, specific root length, root branching intensity, root tissue density, root nitrogen concentration, mycorrhizal association type, carbon translocation to symbionts, and others (Freschet et al., 2021; Pierick et al., 2021) may have important effects on soil carbon and nutrient cycling in upland ecosystems. It is important to note that correlations between above- and belowground traits can be integrated at the whole-plant level (Weigelt et al., 2021), showing the level of coordination between both compartments from which significant functions can emerge like plant growth and carbon accumulation. This combination of traits is even more challenging to scrutinize under the variety of environmental and climatic conditions typical from mountain regions but can contribute to integrating and better understanding the role of both compartments in carbon storage.

There is a pervasive lack of data about how biotic factors influence carbon storage. Biotic interactions play a prominent role in carbon dynamics; for example, feedbacks between plants and their associated soil organisms can influence species growth (Pizano et al., 2019), changes in aboveground arthropods can determine herbivory (Ebeling et al., 2014), and soil macrofauna can drive leaf-litter decomposition (Cárdenas et al., 2017; Four et al., 2019), thus making major contributions to carbon and nutrient cycling in tropical ecosystems (McNaughton et al., 1989; Metcalfe et al., 2014). The effects of biomass and faunal, fungal, and bacterial diversity on different functions such as decomposition, litterfall, aboveground biomass, and fine root production are little known in upland forests. In this regard, experimental studies allowing inclusion and exclusion of these groups may be useful to know the role of these organisms in each component of the carbon cycle (Powers et al., 2009). On the other side, it would be important to examine how carbon allocation and release influence the taxonomical and functional structuring of these biotic communities to extend our view about the implications of carbon cycling on biodiversity processes (see more discussions later).

\subsection{Geographical patterns}

The mountain chain of the tropical Andes is one of the most biodiverse areas globally, and its more than $7000 \mathrm{~km}$ in length encompasses different countries in the region with many populous cities of South America, including La Paz (Bolivia), Cuzco (Peru), Bogotá (Colombia), Mérida (Venezuela), and Quito (Ecuador) (Seyfried et al., 1998; Duque et al., 2021). In addition, Andean mountain forests represent a significant aboveground carbon sink globally and are considered a future carbon refuge due to the declining of carbon sequestering capacity in lowland old-growth tropical forests (Duque et al., 2021). This tropical region was where more studies were conducted, unlike other continents that do 
(a)

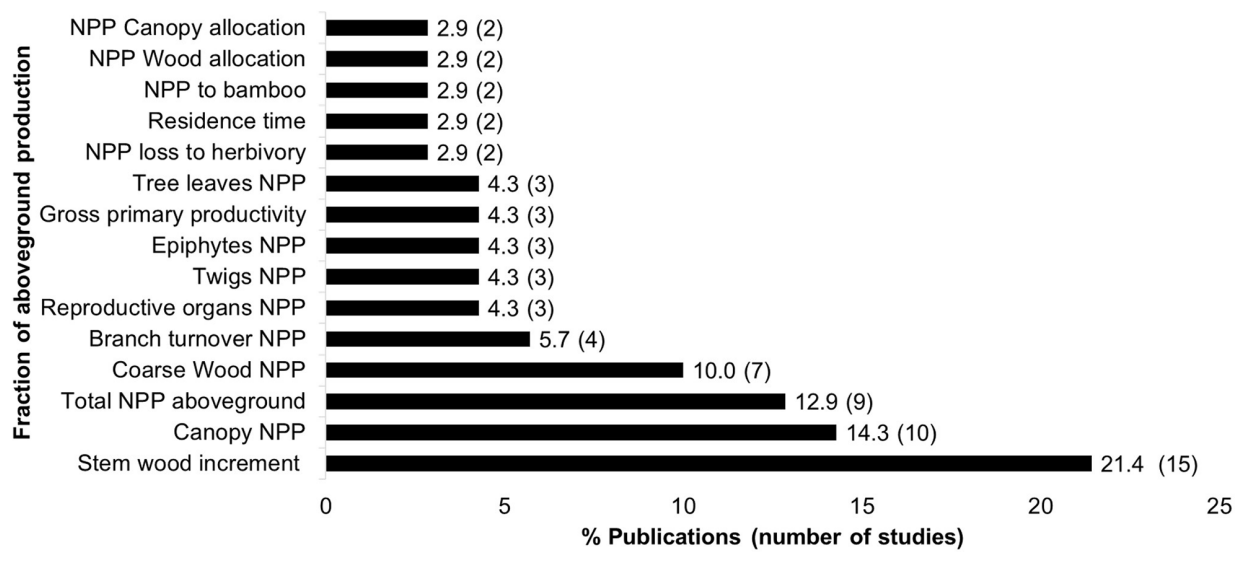

(b)
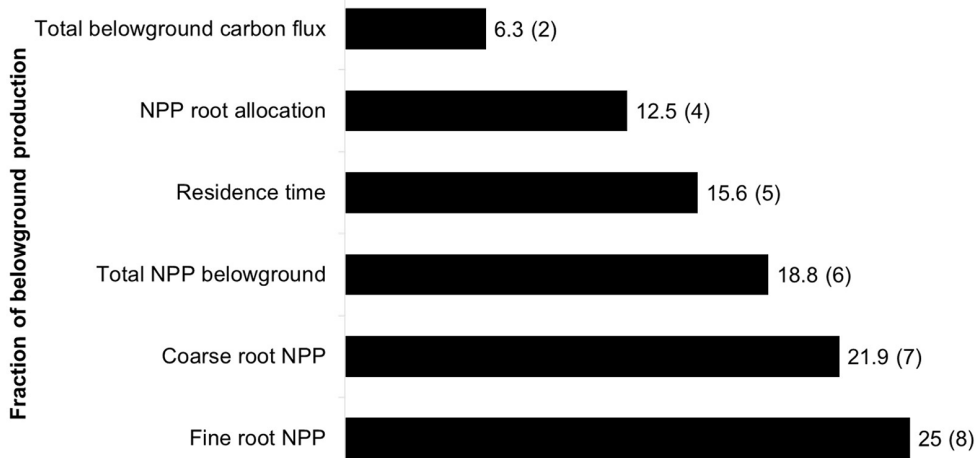

(c)

0
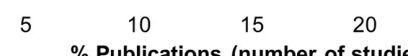

$25 \quad 30$

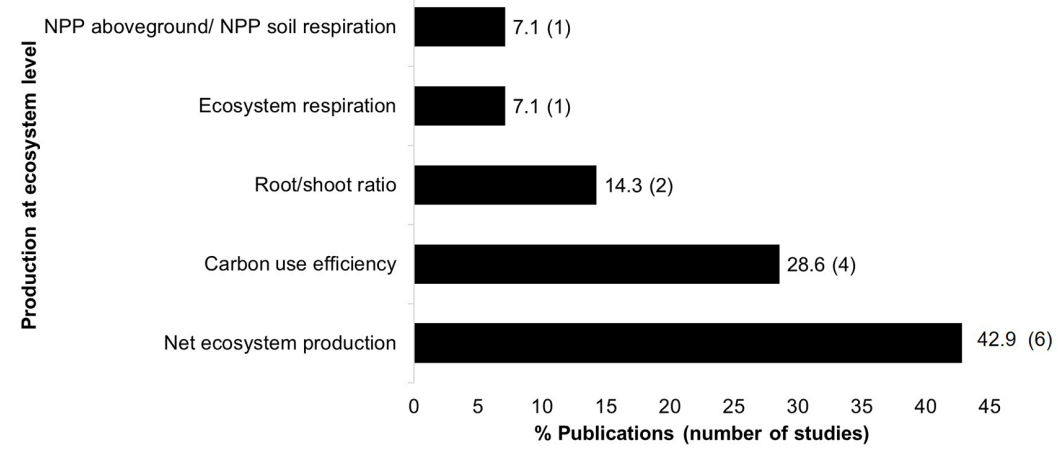

Figure 6. Production fractions for the (a) aboveground compartment, (b) belowground compartment, and (c) ecosystem level.

not have such extensive mountain systems that involve different countries and regions.

The consolidation of biological research stations over important natural areas of mountain forest such as the ZamoraChinchipe Province in Ecuador (Leuschner et al., 2007; Moser et al., 2011; Pinos et al., 2017) or the biological station of Wayqecha in the Kosñipata Valley in Peru (Girardin et al., 2010; Segnini et al., 2011) probably have facilitated the study of carbon allocation, especially under elevational gradients ranging from Amazon forests to high-mountain forests and even paramo ecosystems. In this review most of the stud- ies were conducted at both research stations (21 studies at Zamora Chinchipe and 20 studies in Kosñipata Valley), but it is worth highlighting the importance of other research stations in less studied areas in Bolivia, Argentina, and Colombia to understand the carbon dynamics in the Andean highland forests (Duque et al., 2021). Based on the studies conducted mainly in Ecuador and Peru, two different patterns have been identified regarding the allocation of carbon in the altitudinal gradient. In the Ecuadorian model, with the increase in elevation, most of the biomass is stored in the belowground compartment, while, in the aboveground com- 
partment (biomass, wood density, and maximum tree height) an inverse relationship with altitude is shown (Moser et al., 2011; Calderón-Loor et al., 2020). On the other hand, in the Peruvian model, the allocation of carbon in the above- and belowground compartments is the same from lowland forests to mountain forests (Girardin et al., 2010).

Arguably, the high rainfall in Ecuador can increase runoff, generating more acidic soils with nitrogen limitations, thus requiring a greater investment in roots to compensate for the low availability of nutrients. Conversely, in Peru, when presenting a greater seasonality of rains, there is a higher rate of nutrient mineralization, a reason that would explain a similar allocation in all its compartments according to de la Cruz-Amo et al. (2020). It is important to note that investigations of these patterns in high Andean forests of Bolivia, Venezuela, Argentina, and Colombia can provide new information to better understand how carbon is allocated along this elevational gradient. In particular, the high Andean forests of Colombia show significant heterogeneity in the three branches of the Andes mountain range (Calbi et al., 2021; Hurtado-Martilleti et al., 2021), so that future studies could focus on investigating the carbon cycle over these forests.

I found very few studies in the realms of Afrotropics, Oceania, Indomalayan, and Australasia (Fig. 3b). For a global perspective of carbon cycling, it is necessary to obtain specific information about carbon dynamics over biomes and ecoregions of Asia and Africa, many of which harbour a significant level of plant endemism and are globally hyper-diverse sites (e.g. East African Highlands, Papua New Guinea). Hence, studies focused on root decomposition and turnover may provide important information to understand the contribution of the rhizosphere to belowground carbon storage and how this could be linked to the aboveground compartment (Rahbek et al., 2019). However, information on carbon flux (e.g. plant respiration and decomposition) and biomass allocation (e.g. belowground biomass) is underexplored in the upland forests of these regions, and more research is needed on the factors that regulate these components.

\subsection{Factors analysed in the carbon cycle and methods employed}

In line with previous results, the bulk of papers assessed the effect of elevation on forest biomass (Fig. 4). Overall, elevation has received more attention due to its importance as a natural laboratory that provides a broad climate gradient that allows assessment of the potential effects of global warming on key ecological processes such as carbon sequestration (Malhi et al., 2010; Girardin et al., 2014). Nonetheless, important factors including land use history need to be explored considering the increase in anthropogenic activities in the forests that modify the carbon stocks (Ziter et al., 2013) and promote the increase in greenhouse emissions (Brinck et al.,
2017). This is also linked with the effect of the successional stage to biomass and productivity, which is important to consider, taking into account that secondary forests are becoming a common natural coverage across tropical biomes (Melo et al., 2013; Arroyo-Rodríguez et al., 2017), but their effects on carbon accumulation have not been extensively tested besides some works performed in the Neotropics (Fehse et al., 2002; Farley et al., 2004).

One of the topics that has frequently been neglected in upland ecosystems is fire ecology although it is an important factor in the ecology and dynamics of tropical ecosystems (Román-Cuesta et al., 2011). Specifically, in the context of carbon cycling it is important to understand how fire can alter carbon release to the atmosphere through massive above- and belowground biomass losses and how this may influence other ecological properties associated with forest structure and recovery (Asbjornsen et al., 2005). Considering the high amount of carbon stored in the soil at higher elevations (Dieleman et al., 2013), the ongoing warming that mountain regions are coping with (Litton et al., 2020), and the widespread human-induced fires because of grazing and other agricultural activities (Farley et al., 2013), the vulnerability of these ecosystems to other events such as extreme droughts (e.g. ENSO) may have major impacts on ecosystem recovery, carbon balance, and nutrient cycling (PonetteGonzález et al., 2016), as well as the distribution of the treeline (Román-Cuesta et al., 2011). In this review few studies assessed the effect of fire on carbon balance $(n=7)$, mainly by using pared-plot research design for burned and unburned sites. Additional research in this regard can provide essential information to encourage adaptive fire management and conservation strategies to prevent greenhouse emissions.

Remote sensing and landscape ecology may be useful to establish spatial relations with carbon stocks (Clerici et al., 2016; Taddese et al., 2020); however the results of this review show that this approach needs to be further explored in the upper montane regions (Fig. 4c). Despite some difficulties in the resolution of images linked to the climatic characteristics of the upland ecosystems such as sparse clouds that cause variations in illumination conditions (Clerici et al., 2016), remote-sensing-based approaches ease the measuring of carbon stocks and sequestration not only for producing spatial interpolations but also for including the temporal dynamics of the analysed ecosystems at plot and landscape levels. Nevertheless, more research is required to improve atmospheric and topographic corrections from images to obtain better estimates of aboveground biomass and other ecosystem properties (Clerici et al., 2016).

On the other hand, it is crucial to assess the effect of individual species on both above- and belowground biomass and productivity, especially in the belowground compartment where the individual contribution of species has rarely been the subject of study. Vertical stratification can complement the analyses of belowground production combined with nutrient cycling and distribution in the different soil layers, 
bearing in mind the strong vertical variation and the dramatic changes in organic matter quality, nutrient availability, and hydromorphology along soil profiles (Bahram et al., 2015).

As aforementioned, somewhat critical to consider is the relationship between biomass and biotic variables. In line with this, a topic that remains to be examined is the biodiversity and ecosystem function relationship, especially the diversity-productivity relation. It seems that diversity enhances productivity but on a small scale (Homeier and Leuschner, 2020), and some studies have stressed that the effect of diversity on productivity can increase importantly in long-term experiments (Tilman et al., 2012; Eisenhauer et al., 2013); however, the debate is still open, especially over tropical upland forests. Furthermore, little is known about the top-down regulation of predators in soil food webs that determine soil carbon sequestration and primary productivity and how the soil microbiome interacts with abiotic properties and plant-derived resources (Thakur and Geisen, 2019; Geisen et al., 2019). In addition, it has been posed that changes in species diversity of terrestrial decomposers within and across trophic levels can significantly alter leaf-litter decomposition via trophic cascades (Gessner et al., 2010), but this has been studied mainly on lowland ecosystems (Barnes et al., 2014; Cárdenas et al., 2017). Predator-induced changes on prey stoichiometry represent another important effect on the quality of herbivore biomass added to the litter, which may influence plant-litter decomposition (Hawlena et al., 2012); nonetheless this knowledge is non-existent over upland ecosystems.

Other organisms such as bacteria and fungi are remarkable for their symbiotic relationships that increase plant growth and productivity (Juntahum et al., 2020), yet only a few studies have evaluated the impact of microbial interactions on growth and productivity in upland forests (Urgiles et al., 2009). In particular, some studies have suggested that ectomycorrhizal fungi play a central role in slowing down soil carbon cycling (Koide and Wu, 2003; Averill and Hawkes, 2016); however this pattern (known as the Gadgil effect) has been mainly tested on temperate and boreal forests (Fernandez and Kennedy, 2015), and it is unknown to what extent it occurs on tropical mountain ecosystems where fungal diversity has not yet been well-described (Nottingham et al., 2018). Finally, since mycorrhizal fungal mycelium and their associations with fine roots are considered one of the principal precursors of carbon storage in soil, the estimation of annual litter inputs of roots and their associated mycorrhiza may help understand the belowground dynamics of carbon stocks (Lin et al., 2017).

\subsection{Carbon cycling assessment}

Most of the studies were concentrated on the estimation of carbon stocks, mainly from aboveground as mentioned earlier (Fig. 5a). Nonetheless, it is urgent to better understand the complete carbon cycle with all the components including above- and belowground compartments and their fluxes to determine how mountain ecosystems will respond to increasing human impacts (Malhi et al., 2011; Girardin et al., $2013 b)$. In this sense, comprehensive predictions about the influence of biotic and abiotic drivers on shifts in carbon stocks and fluxes should be investigated.

Notably, for carbon stocks it is not well-understood what is the role of aboveground necromass as well as fine root necromass is in the contribution to carbon storage. Other than to provide habitat for other plants, animals, and microbes, very little has been calculated about the potential role of dead trees and roots in nutrient and carbon cycling in upland forests (Chambers et al., 2000; Palace et al., 2007; Gurdak et al., 2014). Considering the harsh conditions of mountain ecosystems that may increase mortality rates of trees such as limitation of nutrient uptake (Soethe et al., 2006), strong winds (Sugden, 1986), high ultraviolet light exposure (Flenley, 1992), increasing slopes (Werner and Homeier, 2015), and high precipitation (Schuur and Matson, 2001), necromass seems to be an important input that should be taken into account when analysing carbon storage and release. Specifically, different sizes of necromass can add more detail to these estimations as suggested by Palace et al. (2007).

There is a lack of studies about phenology and this could be important for analysing rhythms of the forest productivity fractions in a long-term sectional analysis (Girardin et al., 2014a). This information would allow better prediction of the effect of seasonality and key ambient variables such as solar radiation, humidity, and temperature in the dynamics of NPP of mountain ecosystems. Furthermore, belowground production has been less studied, and this may complement the analysis about how carbon is allocated and redistributed in the compartments over time. The analysis of production at the ecosystem level (i.e. net ecosystem production) remains poorly investigated because of the lack of simultaneous estimations of above- and belowground carbon production (Fig. 6c). In this regard, it is important to consider that missing components of NPP such as root exudates, leaf and root herbivory, and volatile organic carbon compounds can underestimate the carbon use efficiency and allocation in these ecosystems (Malhi et al., 2011).

As pointed out in the results, fluxes were less studied in carbon cycling despite their importance in linking the compartments with the atmosphere and pedosphere. Although litter decomposition is a pivotal process that concentrates more than $90 \%$ of the aboveground NPP production (Cebrian, 1999; Gessner et al., 2010), the understanding of the mechanisms that modulate this ecological process remains to be explored. In fact, only a minor group of species have been studied (Table B2). It is possible that there are few studies on this flux due to the time it takes to carry out this type of decomposition experiment. For instance, in low-temperature ecosystems such as tropical mountain rainforest of the Andes, less than $50 \%$ of litter material is decomposed within the first 12 months, which suggest that long periods of time are required to obtain a more representative approximation 
of the decomposition process in the upland forests (Marian et al., 2017).

Additionally, there are very few studies that incorporate different native plant species to evaluate these processes, for which experiments involving a greater taxonomical and functional variety of plants are required. Considering that litter quality has been posed as one of the main drivers of leaf-litter decomposition (Ristok et al., 2019; Giweta, 2020; Canessa et al., 2021), the inclusion of several species with a broad trait variation that encompasses contrasting ecological strategies (e.g. conservative vs. acquisitive) would allow researchers to parse out different litter types in a comparative axis that provides a representative estimation of the decomposition in these forests (Esquivel et al., 2020 Canessa et al., 2021). Notwithstanding, it is worth highlighting that litter quality is not the only factor that explains decomposition rates, and many other interactive effects of plants, the climate, and soil biota could regulate litter decomposition (Aerts, 1997; Austin et al., 2014). Home-field advantage (Vivanco and Austin, 2008; Veen et al., 2015), substrate-matrix interaction (Freschet et al., 2012), and phenology-substrate match (Pearse et al., 2014) are useful frameworks for exploring the mechanistic underpinning of litter decomposition under different conditions and interactions, thus providing a comprehensive view of the drivers that control decomposition in upland ecosystems. Moreover, other components of the plants such as stems and roots have rarely been subjected to decomposition experiments. Root decomposition is particularly important since upland forests may allocate more root biomass to compensate for low nutrient availability in soils (Leuschner et al., 2007; Moser et al., 2011). Hence, studies focused on root decomposition and turnover may provide important information to understand the contribution of the rhizosphere to belowground carbon storage and how this could be linked to the aboveground compartment.

Soil respiration as well as root, wood, and microbial respiration are essential fluxes that can explain carbon use efficiency of upland forests. There is a growing body of evidence that soil respiration plays a major role in determining a wide range of ecological features ranging from individual plant functioning to the global concentration of atmospheric $\mathrm{CO}_{2}$ (Chimner, 2004; Liu et al., 2006; Murcia-Rodríguez and Ochoa-Reyes, 2008; Zimmermann et al., 2010b; Giardina et al., 2014). Indeed, respiration of soil organic carbon is considered one of the principal fluxes of $\mathrm{CO}_{2}$ on terrestrial ecosystems, and hence understanding the drivers that control soil respiration is paramount for predicting future climate change (Averill and Hawkes, 2016). In addition, respiration is an important link to above- and belowground compartments because it is tied to vegetation structure, plant phenology, photosynthetic activity, and fine root and microbial biomass (Rosero et al., 2020; Adachi et al., 2006). Nevertheless, respiration was one of the less studied processes in this review (Fig. 5b), so the knowledge of this flux constitutes an important gap to fill in further studies over upland forests.

\subsection{What do we still need to know?}

Carbon cycle is a very complex process that involves several properties and interactions between components and can vary importantly in the tropics. However, much that we know comes from altitudinal gradients in the Ecuadorian and Peruvian Andes, but many other ecoregions of the Andean region, African mountains, and southeastern Asia have limited information of different components that integrate the carbon cycle. Important regions including northern South America, rift valleys, Papua New Guinea, and mountains in the Indomalayan islands need to be further explored.

Fine root biomass and production are critical to understanding the interaction between above- and belowground compartments which may better integrate the carbon in the biogeochemical cycle. Nevertheless, in this review few studies assessed both compartments concomitantly (18.51\%; $n=25$ ). It is also unknown how necromass contributes to carbon cycling and how fluxes such as leaf-litter and root decomposition release carbon to the atmosphere as well as incorporate nutrients to the soil systems. With necromass being one of the largest stocks of the total carbon pool in tropical forests (Palace et al., 2007), this component should constitute a future research avenue in carbon cycling. Currently, there is a vigorous debate about whether decomposition affects the increase in carbon emissions or enhances carbon sequestration via plant growth by releasing limited nutrients like nitrogen in very low-resource environments such as mountain forests (Bothwell et al., 2014). Integration of above- and belowground stocks and fluxes is necessary to analyse the response of upland ecosystems to future climate change. However, I found very few studies that simultaneously related the above- and belowground compartments with the fluxes $(11.11 \% ; n=15)$, which is imperative to fully understanding the carbon cycle.

The incorporation of functional traits related to carbon cycling is a missing link that needs to be parsed out in these ecosystems. Information of functional traits from highland mountains is scarce on basic traits such as wood density, foliar traits, and root traits and, even more so for hard traits associated with plant physiology. Gathering this type of information and establishing the relationships between traits from both compartments may shed light on the characteristics that better predict carbon accumulation over these ecosystems.

Future analysis of the carbon cycle needs to explore ecological gradients such as nutrient resources and successional gradients. In the former, the relations with nutrient cycling would be important to know for how enrichment conditions of several soil elements sustain forest productivity in each compartment but also in their fluxes. This is important considering the extensive agricultural activities performed in mountain ecosystems in which there is an intense use of fertilizers and agrochemicals on the soil, yet very little is known about the impacts on carbon cycling. In the case of successional gradients, despite some studies having suggested that 
secondary forests can rapidly recover their species richness promoting carbon storage and sequestration (Rozendaal et al., 2019), these models have been generally performed on lowland ecosystems, and it is not well-established if the same pattern occurs in the upland region.

Admittedly, the influence of biotic interactions on every single component of the carbon cycle is still unexplored. All the organisms associated with plants from microbial communities to large terrestrial predators may have subsequent effects on carbon storage and release, but we have no knowledge about the functional role of many of these species. This is worth mentioning because biotic interactions can maintain several functions and we do not know to what extent the loss of species and interactions may impact litterfall, biomass, production, decomposition, or respiration.

Ultimately, as a conservation strategy to mitigate global warming, the monitoring of upland regions and the establishment of their connectivity to the lowlands have been suggested (Malhi et al., 2010). Therefore, the assessment of every component pointed out in this review may lead us to an in-depth understanding of the biogeochemical cycle, and for this the long-term monitoring is critical, especially in the upland regions where ecosystem dynamics are generally slowed down. Indeed, more complete information on ecological properties of these ecosystems comes from longitudinal studies conducted in permanent plots in many of the aforementioned sites. In line with this, the combination of different research networks at a regional or global scale as well as open data science can contribute to unveiling general patterns of carbon balance as previous studies have demonstrated (e.g. Duque et al., 2021; Powers et al., 2009; Wall et al., 2008).

\section{Conclusions}

The take-home lessons of this review can be described as follows. (1) There were differential patterns in the number of publications about the carbon cycle over high-mountain tropical forests where biomes and ecoregions from the Neotropics were studied to a greater extent (especially in the Andes). This brings attention to the need to explore many other ecoregions to have a big picture about the carbon cycling in the tropical uplands. (2) Elevational gradient was the topic most studied, but other critical aspects such as successional gradient, landscape management, diversity-productivity relationship, functional-trait-based approach, faunal and microbial effect, trophic cascades, Gadgil effect, and fire ecology require more attention for a comprehensive understanding of the carbon cycle. (3) The estimation of aboveground and soil carbon stocks was the component most quantified, while fluxes such as litterfall, respiration, and litter decomposition comprised a quarter of the studies. (4) The inclusion of several litter species and origins other than leaves (i.e. roots and stems) in decomposition experiments as well as theoretical frameworks including home-field advantage, substrate-matrix interaction, and phenology-substrate match may provide useful information and explanatory mechanisms that help disentangle the complex process of litter decomposition over these ecosystems. (5) Despite respiration being a paramount link that is closely tied to above- and belowground compartments, this flux was less studied in this review and, therefore, constitutes one important gap to study in future research. (6) Finally, to better understand the carbon cycle, knowledge of its main fluxes is necessary in climate change mitigation plans, which is seen as one of the main threats to ecosystem functioning in the coming years. 
Appendix A

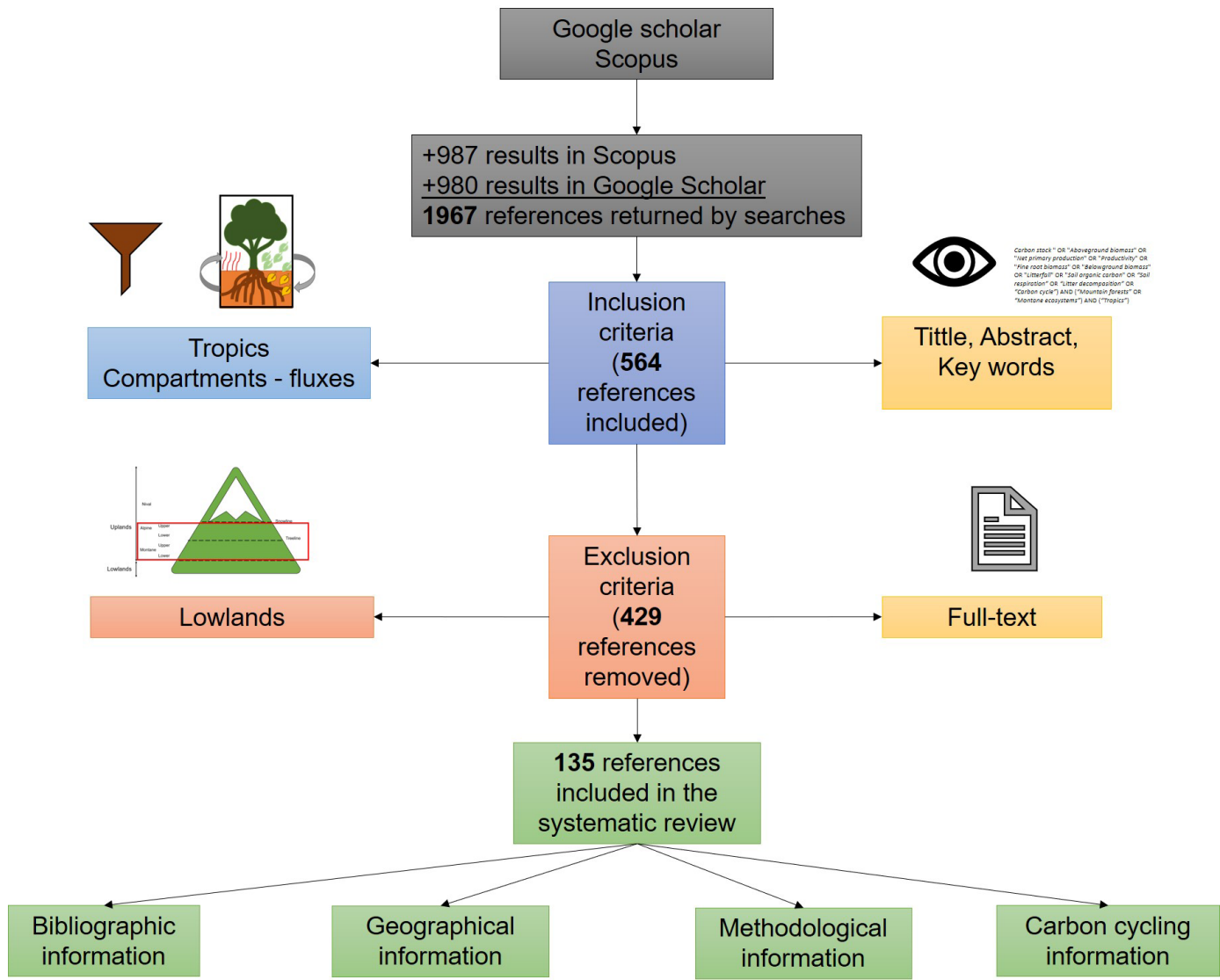

Figure A1. Procedure for selecting the studies in the systematic review of the carbon cycle in tropical upland ecosystems. Grey boxes indicate results from databases. Blue and red boxes represent the inclusion and exclusion criteria, respectively, and orange boxes show what components of the paper analysed those criteria. Green boxes indicate how the selected studies where scrutinized.

\section{Appendix B}

Table B1. List of references selected in the systematic review of the carbon cycle in tropical upland ecosystems.

\begin{tabular}{ll}
\hline 1 & Aiba et al. (2005) \\
2 & Aiba et al. (2007) \\
3 & Álvarez-Arteaga et al. (2013) \\
4 & Alvarez et al. (2012) \\
5 & Allvarez-Dávila et al. (2017) \\
6 & Asbjornsen et al. (2005) \\
7 & Asrat et al. (2020) \\
8 & Bothwell et al. (2014) \\
9 & Brujinzeel et al. (2011) \\
10 & Butenschoen et al. (2014) \\
11 & Calderón-Loor et al. (2020) \\
12 & Chimner (2004) \\
13 & Chimner and Karberg (2008) \\
\hline
\end{tabular}

Table B1. Continued.

\begin{tabular}{ll}
\hline 14 & Chiti et al. (2018) \\
15 & Cizungu et al. (2014) \\
16 & Clark et al. (2016) \\
17 & Clark et al. (2017) \\
18 & Clark et al. (2015) \\
19 & Clerici et al. (2016) \\
20 & Coûteaux et al. (2002) \\
21 & Culmsee et al. (2010) \\
22 & Cuni-Sanchez et al. (2017) \\
23 & Dalling et al. (2016) \\
24 & de la Cruz-Amo et al. (2020) \\
25 & Dielman et al. (2013) \\
26 & Esquivel et al. (2020) \\
27 & Fahey et al. (2016) \\
28 & Farley et al. (2004) \\
29 & Farley et al. (2013) \\
30 & Fehse et al. (2002) \\
\hline
\end{tabular}


Table B1. Continued.

\begin{tabular}{|c|c|}
\hline 31 & Fisher et al. (2013) \\
\hline 32 & Fox et al. (2010) \\
\hline 33 & Gebeyehu et al. (2019) \\
\hline 34 & Giadina et al. (2014) \\
\hline 35 & Gibbon et al. (2010) \\
\hline 36 & Girardin et al. (2014b) \\
\hline 37 & Girardin et al. (2013a) \\
\hline 38 & Girardin et al. (2013b) \\
\hline 39 & Girardin et al. (2010) \\
\hline 40 & Girardin et al. (2014a) \\
\hline 41 & Gonzàlez-Jarmillo et al. (2018) \\
\hline 42 & Graefe et al. (2008a) \\
\hline 43 & Graefe et al. (2008b) \\
\hline 44 & Guillozet et al. (2015) \\
\hline 45 & Gurdak et al. (2014) \\
\hline 46 & Heitkamp et al. (2014) \\
\hline 47 & Hobbie (2000) \\
\hline 48 & Homeier and Leuschner (2021) \\
\hline 49 & Homeier et al. (2021) \\
\hline 50 & Homeier et al. (2010) \\
\hline 51 & Illig et al. (2008) \\
\hline 52 & Kitayama et al. (2000) \\
\hline 53 & Kitayama and Aiba (2002) \\
\hline 54 & Kübler et al. (2020) \\
\hline 55 & Lemenih and Itanna (2004) \\
\hline 56 & León et al. (2011) \\
\hline 57 & Leuschner et al. (2007) \\
\hline 58 & Leuschner et al. (2013) \\
\hline 59 & Litton et al. (2020) \\
\hline 60 & Litton et al. (2011) \\
\hline 61 & Malhi et al. (2017) \\
\hline 62 & Marian et al. (2017) \\
\hline 63 & Marian et al. (2018) \\
\hline 64 & Marthews et al. (2012) \\
\hline 65 & Moser et al. (2010) \\
\hline 66 & Moser et al. (2011) \\
\hline 67 & Moser et al. (2008) \\
\hline 68 & Moser et al. (2007) \\
\hline 69 & Murcia-Rodriguez and Ochoa-Reyes (2008) \\
\hline 70 & Murcia-Rodríguez et al. (2012) \\
\hline 71 & Nierop et al. (2007) \\
\hline 72 & Nottingham et al. (2012) \\
\hline 73 & Nyirambangutse et al. (2017) \\
\hline 74 & Oliveras et al. (2014) \\
\hline 75 & Peña et al. (2010) \\
\hline 76 & Phillips et al. (2019) \\
\hline 77 & Phillips et al. (2016) \\
\hline 78 & Pinos et al. (2017) \\
\hline 79 & Ponette-González et al. (2016) \\
\hline 80 & Powers et al. (2009) \\
\hline 81 & Quichimbo et al. (2017) \\
\hline 82 & Raich et al. (2006) \\
\hline 83 & Ramírez-Correa et al. (2007) \\
\hline 84 & Ramos Scharrón et al. (2012) \\
\hline 85 & Rapp et al. (2012) \\
\hline
\end{tabular}

Table B1. Continued.

\begin{tabular}{|c|c|}
\hline 86 & Röderstein et al. (2005) \\
\hline 87 & Rodríguez-Alarcón et al. (2018) \\
\hline 88 & Román-Cuesta et al. (2011) \\
\hline 89 & Romero-Torres and Varela-Ramírez (2011) \\
\hline 90 & Rosero et al. (2020) \\
\hline 91 & Salinas et al. (2011) \\
\hline 92 & Schawe et al. (2007) \\
\hline 93 & Schuur (2001) \\
\hline 94 & Schuur and Matson (2001) \\
\hline 95 & Scowcroft et al. (2000) \\
\hline 96 & Segnini et al. (2011) \\
\hline 97 & Selmants et al. (2014) \\
\hline 98 & Selmants et al. (2016) \\
\hline 99 & Shirima et al. (2015) \\
\hline 100 & Simegn and Soromessa (2015) \\
\hline 101 & Soethe et al. (2007) \\
\hline 102 & Soethe et al. (2006) \\
\hline 103 & Soethe et al. (2008) \\
\hline 104 & Spracklen and Righelato (2014) \\
\hline 105 & Spracklen and Righelato (2016) \\
\hline 106 & Suárez and Medina (2001) \\
\hline 107 & Taddese et al. (2020) \\
\hline 108 & Tonneijck and Jongmans (2008) \\
\hline 109 & Tonneijck et al. (2010) \\
\hline 110 & Unger et al. (2012) \\
\hline 111 & Varela et al. (2003) \\
\hline 112 & Varela et al. (2007) \\
\hline 113 & Vázquez et al. (2014) \\
\hline 114 & Velescu et al. (2016) \\
\hline 115 & Wall et al. (2008) \\
\hline 116 & Wanyama et al. (2019) \\
\hline 117 & Werner and Homeier (2015) \\
\hline 118 & Whitaker et al. (2014) \\
\hline 119 & Wilcke et al. (2008) \\
\hline 120 & Wilcke et al. (2005) \\
\hline 121 & Wilcke et al. (2002) \\
\hline 122 & Wittich et al. (2012) \\
\hline 123 & Wolf et al. (2011) \\
\hline 124 & Yepes et al. (2016) \\
\hline 125 & Yepes et al. (2015) \\
\hline 126 & Yimer et al. (2006) \\
\hline 127 & Zach et al. (2010) \\
\hline 128 & Zach et al. (2008) \\
\hline 129 & Zapata-Duque et al. (2007) \\
\hline 130 & Zimmermann et al. (2010a) \\
\hline 131 & Zimmermann et al. (2012) \\
\hline 132 & Zimmermann et al. (2010b) \\
\hline 133 & Zimmermann et al. (2009a) \\
\hline 134 & Zimmermann et al. (2009b) \\
\hline 135 & Zúñiga-Escobar et al. (2013) \\
\hline
\end{tabular}


Table B2. Species studied in litter decomposition experiments conducted in tropical upland ecosystems.

\begin{tabular}{|c|c|c|c|c|}
\hline Litter species & Time harvesting & Site & Elevation range $(\mathrm{m})$ & Reference \\
\hline Acalypha communis & $\begin{array}{l}10 \text { times }(30,60, \\
90,120,180,240, \\
300,360,450,540 \\
\text { months) }\end{array}$ & Costa Rica & $2150-2950$ & Esquivel et al. (2020) \\
\hline Hyeronima oblonga & $\begin{array}{l}10 \text { times }(30,60, \\
90,120,180,240, \\
300,360,450,540 \\
\text { months) }\end{array}$ & Costa Rica & $2150-2950$ & Esquivel et al. (2020) \\
\hline Alchornea latifolia & $\begin{array}{l}10 \text { times }(30,60, \\
90,120,180,240, \\
300,360,450,540 \\
\text { months) }\end{array}$ & Costa Rica & $2150-2950$ & Esquivel et al. (2020) \\
\hline Quercus bumelioides & $\begin{array}{l}10 \text { times }(30,60, \\
90,120,180,240, \\
300,360,450,540 \\
\text { months) }\end{array}$ & Costa Rica & $2150-2950$ & Esquivel et al. (2020) \\
\hline Jarava ichu & $\begin{array}{l}10 \text { times }(30,60, \\
90,120,180,240, \\
300,360,450,540 \\
\text { months) }\end{array}$ & Costa Rica & $2150-2950$ & Esquivel et al. (2020) \\
\hline Minquartia guianensis & $\begin{array}{l}10 \text { times }(30,60, \\
90,120,180,240, \\
300,360,450,540 \\
\text { months) }\end{array}$ & Costa Rica & $2150-2950$ & Esquivel et al. (2020) \\
\hline Magnolia sororum & $\begin{array}{l}10 \text { times }(30,60, \\
90,120,180, \\
240,300,360,450,540 \\
\text { months) }\end{array}$ & Costa Rica & $2150-2950$ & Esquivel et al. (2020) \\
\hline Vochysia allenii & $\begin{array}{l}10 \text { times }(30,60, \\
90,120,180,240, \\
300,360,450,540 \\
\text { months) }\end{array}$ & Costa Rica & $2150-2950$ & Esquivel et al. (2020) \\
\hline Pourouma bicolor & $\begin{array}{l}10 \text { times }(30,60, \\
90,120,180,240, \\
300,360,450,540 \\
\text { months) }\end{array}$ & Costa Rica & $2150-2950$ & Esquivel et al. (2020) \\
\hline Carapa guianensis & $\begin{array}{l}10 \text { times }(30,60, \\
90,120,180,240, \\
300,360,450,540 \\
\text { months) }\end{array}$ & Costa Rica & $2150-2950$ & Esquivel et al. (2020) \\
\hline Polylepis reticulata & $\begin{array}{l}7 \text { times }(30,60,90,150, \\
210,300,365 \\
\text { months) }\end{array}$ & Peru & $3735-3930$ & Pinos et al. (2017) \\
\hline Puteria sp. & $\begin{array}{l}5 \text { times }(6,12,24,36,48 \\
\text { months) }\end{array}$ & Ecuador & $1000-3000$ & Marian et al. (2017) \\
\hline Cavendishia sp. & $\begin{array}{l}5 \text { times }(6,12,24,36,48 \\
\text { months) }\end{array}$ & Ecuador & $1000-3000$ & Marian et al. (2017) \\
\hline Mollinedia sp. & $\begin{array}{l}5 \text { times }(6,12,24,36,48 \\
\text { months) }\end{array}$ & Ecuador & $1000-3000$ & Marian et al. (2017) \\
\hline
\end{tabular}


Table B2. Continued.

\begin{tabular}{|c|c|c|c|c|}
\hline Litter species & Time harvesting & Site & Elevation range $(\mathrm{m})$ & Reference \\
\hline \multirow[t]{3}{*}{$\begin{array}{l}\text { Graffenrieda } \\
\text { emarginata }\end{array}$} & $\begin{array}{l}5 \text { times }(6,12,24,36,48 \\
\text { months) }\end{array}$ & Ecuador & $1000-3000$ & Marian et al. (2017) \\
\hline & 3 times $(6,12,24$ months $)$ & Ecuador & 2000 & Butenschoen et al. (2014) \\
\hline & 3 times (2, 6, 12 months) & Ecuador & $1850-2280$ & Illig et al. (2008) \\
\hline Clusia sp. & $\begin{array}{l}5 \text { times }(6,12,24,36,48 \\
\text { months) }\end{array}$ & Ecuador & $1000-3000$ & Marian et al. (2017) \\
\hline Hediosmum sp. & $\begin{array}{l}5 \text { times }(6,12,24,36,48 \\
\text { months) }\end{array}$ & Ecuador & $1000-3000$ & Marian et al. (2017) \\
\hline \multirow{4}{*}{$\begin{array}{l}\text { Metrosideros } \\
\text { polymorpha }\end{array}$} & 3 times $(1,3,6$ months $)$ & Hawaii & $800-1600$ & Bothwell et al. (2014) \\
\hline & $\begin{array}{l}6 \text { times }(1,6,12,18,24, \\
30 \text { months })\end{array}$ & Hawaii & $800-2410$ & Hobbie et al. (2000) \\
\hline & $\begin{array}{l}8 \text { times }(1,3,6,12, \\
18,24,30,36 \text { months })\end{array}$ & Hawaii & $410-1780$ & Scowcroft et al. (2000) \\
\hline & $\begin{array}{l}5 \text { times }(1,3,6,9, \\
15 \text { months })\end{array}$ & Hawaii & $1270-1370$ & Schurr (2001) \\
\hline Clusia alata & $\begin{array}{l}7 \text { times }(7,14,28,56,112, \\
224,448 \text { d) }\end{array}$ & Peru & $2720-3025$ & Salinas et al. (2011) \\
\hline $\begin{array}{l}\text { Nectandra } \\
\text { longifolia }\end{array}$ & $\begin{array}{l}7 \text { times }(7,14,28,56,112, \\
224,448 \text { d) }\end{array}$ & Peru & $2720-3025$ & Salinas et al. (2011) \\
\hline $\begin{array}{l}\text { Weinmannia } \\
\text { bangii }\end{array}$ & $\begin{array}{l}7 \text { times }(7,14,28,56, \\
112,224,448 \mathrm{~d})\end{array}$ & Peru & $2720-3025$ & Salinas et al. (2011) \\
\hline $\begin{array}{l}\text { Weinmannia } \\
\text { crassifolia }\end{array}$ & $\begin{array}{l}7 \text { times }(7,14,28,56, \\
112,224,448 d)\end{array}$ & Peru & $2720-3025$ & Salinas et al. (2011) \\
\hline $\begin{array}{l}\text { Hesperomeles } \\
\text { ferruginea }\end{array}$ & $\begin{array}{l}7 \text { times }(7,14,28,56, \\
112,224,448 \mathrm{~d})\end{array}$ & Peru & $2720-3025$ & Salinas et al. (2011) \\
\hline $\begin{array}{l}\text { Myrcia } \\
\text { pubescens }\end{array}$ & 3 times $(6,12,24$ months $)$ & Ecuador & 2000 & Butenschoen et al. (2014) \\
\hline $\begin{array}{l}\text { Dictyocaryum } \\
\text { lamarckianum }\end{array}$ & 3 times $(6,12,24$ months $)$ & Ecuador & 2000 & Butenschoen et al. (2014) \\
\hline $\begin{array}{l}\text { Cavendisha } \\
\text { zamorensis }\end{array}$ & 3 times $(6,12,24$ months $)$ & Ecuador & 2000 & Butenschoen et al. (2014) \\
\hline Clusia spp. & 3 times $(6,12,24$ months $)$ & Ecuador & 2000 & Butenschoen et al. (2014) \\
\hline $\begin{array}{l}\text { Cecropia } \\
\text { andina }\end{array}$ & 3 times $(6,12,24$ months $)$ & Ecuador & 2000 & Butenschoen et al. (2014) \\
\hline $\begin{array}{l}\text { Purdiaea } \\
\text { nutans }\end{array}$ & 3 times $(2,6,12$ months $)$ & Ecuador & $1850-2280$ & Illig et al. (2008) \\
\hline $\begin{array}{l}\text { Parinari } \\
\text { excelsa }\end{array}$ & $\begin{array}{l}5 \text { times }(31,61,92,189, \\
316 \mathrm{~d})\end{array}$ & Rwanda & $1854-1934$ & Cizungu et al. (2014) \\
\hline $\begin{array}{l}\text { Cleistanthus } \\
\text { polystachyus }\end{array}$ & $\begin{array}{l}5 \text { times }(31,61,92,189, \\
316 \mathrm{~d})\end{array}$ & Rwanda & $1854-1934$ & Cizungu et al. (2014) \\
\hline $\begin{array}{l}\text { Carapa } \\
\text { grandiflora }\end{array}$ & $\begin{array}{l}5 \text { times }(31,61,92,189, \\
316 \mathrm{~d})\end{array}$ & Rwanda & 1854-1934 & Cizungu et al. (2014) \\
\hline $\begin{array}{l}\text { Eucalyptus } \\
\text { saligna }\end{array}$ & $\begin{array}{l}5 \text { times }(31,61,92,189, \\
316 \mathrm{~d})\end{array}$ & Rwanda & $1854-1934$ & Cizungu et al. (2014) \\
\hline $\begin{array}{l}\text { Eucalyptus } \\
\text { maidenii }\end{array}$ & $\begin{array}{l}5 \text { times }(31,61,92,189, \\
316 \mathrm{~d})\end{array}$ & Rwanda & 1854-1934 & Cizungu et al. (2014) \\
\hline
\end{tabular}


Code availability. There is no underlying code to be made available.

Data availability. All data used are either presented or referred to in the text and are based on the 135 studies listed in Table B1.

Competing interests. The contact author has declared that there are no competing interests.

Disclaimer. Publisher's note: Copernicus Publications remains neutral with regard to jurisdictional claims in published maps and institutional affiliations.

Acknowledgements. I am grateful to Juan M. Posada for insightful ideas and discussions about carbon cycling in the tropical uplands.

Financial support. This research has been supported by Universidad del Rosario (Bogotá, Colombia) under the doctoral student fellowship "Apoyo al talento científico" (grant no. 1570).

Review statement. This paper was edited by Daniel Montesinos and reviewed by two anonymous referees.

\section{References}

Adachi, M., Bekku, Y. S., Rashidah, W., Okuda, T., and Koizumi, H.: Differences in soil respiration between different tropical ecosystems, Appl. Soil Ecol., 34, 258-265, https://doi.org/10.1016/j.apsoil.2006.01.006, 2006.

Aerts, R.: Climate, leaf litter chemistry and leaf litter decomposition in terrestrial ecosystems: A triangular relationship, Oikos, 79, 439-449, https://doi.org/10.2307/3546886, 1997.

Aiba, S., Takyu, M., and Kitayama, K.: Dynamics, productivity and species richness of tropical rainforests along elevational and edaphic gradients on Mount Kinabalu, Borneo, Ecol. Res., 20, 279-286, https://doi.org/10.1007/s11284-005-0043-z, 2005.

Aiba, S., Hanya, G., Tsujino, R., Takyu, M., Kimura, K., and Kitayama, K.: Comparative study of additive basal area of conifers in forest ecosystems along elevational gradients, Ecol. Res., 22, 439-450, https://doi.org/10.1007/s11284-007-0338-3, 2007.

Allvarez-Dávila, E., Cayuela, L, González-Caro, S., Aldana A. M., Stevenson, P. R., Phillips, O., Cogollo, A., Peñuela, M. C., von Hildebrand, P., Jiménez, E., Melo, O., LondoñoVega, A. C., Mendoza, I., Velásquez, O., Fernández, F., Serna, M., Velázquez-Rua, C., Benítez, D., and Rey-Benayas, J. M.: Forest biomass density across large climate gradients in northern South America is related to water availability but not with temperature, PLoS ONE, 12, e0171072, https://doi.org/10.1371/journal.pone.0171072, 2017.
Alvarez, E., Duque, A., Saldarriaga, J., Cabrera, K., de las Salas, G., del Valle, I., Lema, A., Moreno, F., Orrego, S., and Rodríguez, L.: Tree above-ground biomass allometries for carbon stocks estimation in the natural forests of Colombia, Forest. Ecol. Manage., 267, 297-308, https://doi.org/10.1016/j.foreco.2011.12.013, 2012.

Álvarez-Arteaga, G., García-Calderón, N. E., Krasilnikov, P., and García-Oliva, F.: Almacenes de carbono en bosques montanos de niebla de la Sierra Norte de Oaxaca, México, Agrociencia, 47, 171-180, 2013.

Arroyo-Rodríguez, V., Melo, F. P. L., Martínez-Ramos, M., Bongers, F., Chazdon, R. L., Meave, J. A., Norden, N., Santos, B. A., Leal, R. I., and Tabarelli, M.: Multiple successional pathways in human-modified tropical landscapes: new insights from forest succession, forest fragmentation and landscape ecology research, Biol. Rev., 92, 326-340, https://doi.org/10.1111/brv.12231, 2017.

Asbjornsen, H., Velázquez-Rosas, N., García-Soriano, R., and Gallardo-Hernández, C.: Deep ground fires cause massive above- and below-ground biomass losses in tropical montane cloud forests in Oaxaca, Mexico, J. Trop. Ecol., 21, 427-434, https://doi.org/10.1017/S0266467405002373, 2005.

Asrat, Z., Eid, T., Gobakken, T., and Negash, M.: Aboveground tree biomass prediction options for the Dry Afromontane forests in south-central Ethiopia, Forest Ecol. Manage., 473, 118335, https://doi.org/10.1016/j.foreco.2020.118335, 2020.

Austin, A. T., Vivanco, L., González-Arzac, A., and Pérez, L. I.: There's no place like home? An exploration of the mechanisms behind plant litter-decomposer affinity in terrestrial ecosystems, New Phytol., 204, 307-314, https://doi.org/10.1111/nph.12959, 2014.

Averill, C. and Hawkes, C. V.: Ectomycorrhizal fungi slow soil carbon cycling, Ecol. Lett., 19, 937-947, https://doi.org/10.1111/ele.12631, 2016.

Bahram, M., Peay, K. G., and Tedersoo, L.: Local-scale biogeography and spatiotemporal variability in communities of mycorrhizal fungi, New Phytol., 205, 1454-1463, https://doi.org/10.1111/nph.13206, 2015.

Barnes, A., Jochum, M., Mumme, S., Haneda, N. F., Farajallah, A., Widarto, T. H., and Brose, U.: Consequences of tropical land use for multitrophic biodiversity and ecosystem functioning, Nat Commun., 5, 5351, https://doi.org/10.1038/ncomms6351, 2014.

Bar-On, Y. M., Phillips, R., and Milo, R.: The biomass distribution on Earth, P. Natl. Acad. Sci. USA, 115, 6506-6511, https://doi.org/10.1073/pnas.1711842115, 2018.

Beer, C., Reichstein, M., Tomelleri, E., Ciais, P., Jung, M., Carvalhais, N., Rödenbeck, C., Arain, M. A., Baldocchi, D., Bonan, G. B., Bondeau, A., Cescatti, A., Lasslop, G., Lindroth, A., Lomas, M., Luyssaert, S., Margolis, H., Oleson, K. W., Roupsard, O., Veenendaal, E., Viovy, N., Williams, C., Woodward, F. I., and Papale, D.: Terrestrial gross carbon dioxide uptake: global distribution and covariation with climate, Science, 329, 834-838, https://doi.org/10.1126/science, 2010.

Bendix, J., Aguire, N., Beck, E., Bräuning, A., Brandl, R., Breuer, L., Böhning-Gaese, K., Dantas de Paula, M., Hicker, T., Homeier, J., Leuschner, C., Neuschulz, E. L., Schleuing, M., Suarez, J. P., Trachte, K., Wiclke, W., Windhorst, D., and Farwig, N.: A research framework for projecting ecosystem change in highly 
diverse tropical mountain ecosystems, Oecologia, 195, 589-600, https://doi.org/10.1007/s00442-021-04852-8, 2021.

Bonan, G. B.: Forests and climate change: forcings, feedbacks, and the climate benefits of forests, Science, 320, 1444-1449, https://doi.org/10.1126/science.1155121, 2008.

Bothwell, L. D., Selmants, P. C., Giardina, C. P., and Litton, C. M.: Leaf litter decomposition rates increase with rising mean annual temperature in Hawaiian tropical montane wet forests, Peer J., 2, e685, https://doi.org/10.7717/peerj.685, 2014.

Brinck, K., Fischer, R., Groeneveld, J., Lehmann, S., De Paula, M. D., Pütz, S., Sexton, J. O., Song, D., and Huth, A.: High resolution analysis of tropical forest fragmentation and its impact on the global carbon cycle, Nat Commun., 8, 14855, https://doi.org/10.1038/ncomms14855, 2017.

Brown, S. and Lugo, A. E.: Tropical secondary forests, J. Trop. Ecol., 6, 1-32, https://doi.org/10.1017/S0266467400003989, 1990.

Brujinzeel, L. A., Kappelle, M., Mulligan, M., and Scatena, F. N.: Tropical montane cloud forests: state of knowledge and sustainability perspectives in a changing world, in: Tropical Montane Cloud Forests, edited by: Brujinzeel, L. A., Scatena, F. N., and Hamilton, L. S., Cambridge University Press, Cambridge, UK, 691-739, https://doi.org/10.1017/CBO9780511778384.074, 2011.

Butenschoen, O., Krashevska, V., Maraun, M., Marian, F., Sandmann, D., and Scheu, S.: Litter mixture effects on decomposition in tropical montane rainforests vary strongly with time and turn negative at later stages of decay, Soil Biol. Biochem., 77, 121128, https://doi.org/10.1016/j.soilbio.2014.06.019, 2014.

Cárdenas, R., Donos, D. A., Argoti A., and Dangles O.: Functional consequences of realistic extinction scenarios in Amazonian soil food webs, Ecosphere, 8, e01692, https://doi.org/10.1002/ecs2.1692, 2017.

Calbi, M., Fajardo-Gutiérrez, F., Posada, J., Lücking, R., Brokamp, G., and Borsch T.: Seeing the wood despite the trees: Exploring human disturbance impact on plant diversity, community structure, and standing biomass in fragmented high Andean forests, Ecol. Evol., 11, 2110-2172, https://doi.org/10.1002/ece3.7182, 2021.

Calderón-Loor, M., Cuesta, F., Pinto, E., and Gosling, W. D.: Carbon sequestration rates indicate ecosystem recovery following human disturbance in the equatorial Andes. PLoS ONE, 15, e0230612, https://doi.org/10.1371/journal.pone.0230612, 2020.

Canessa, R., van den Brink, L., Saldaña, A., Rios, R. S., Hättenschwiler, S., Mueller, C. W., Prater, I., Tielbörger, J., and Bader, M. Y.: Relative effects of climate and litter traits on decomposition change with time, climate and trait variability, J. Ecol., 109, 447-458, https://doi.org/10.1111/1365-2745.13516, 2021.

Cebrian, J.: Patterns in the fate of production in plant communities, Am. Nat., 154, 449-468, https://doi.org/10.1086/303244, 1999.

Chambers, J. Q., Higuchi, N., Schimel, J. P., Ferreira, L. V., and Melack, J. M.: Decomposition and carbon cycling of dead trees in tropical forests of the central Amazon, Oecologia, 122, 380388, https://doi.org/10.1007/s004420050044, 2000.

Chimner, R. A.: Soil respiration rates of tropical peatlands in Micronesia and Hawaii, Wetlands, 24, 51-56, 2004.

Chimner, R. A. and Karberg, J. M.: Long-term carbon accumulation in two tropical mountain peatlands, Andes Mountains, Ecuador, Mires Peat, 3, 1-10, 2008.
Chiti, T., Díaz-Pinés, E., Butterbach-Bahl, K., Marzaioli, F., and Valentini, R.: Soil organic carbon changes following degradation and conversion to cypress and tea plantations in a tropical mountain forest in Kenya, Plant Soil, 422, 527-539, https://doi.org/10.1007/s11104-017-3489-1, 2018.

Cizungu, L., Staelens, J., Huygens, D., Walangululu, J., Muhindo, D., Van Cleemput, O., and Boeckx, P.: Litterfall and leaf litter decomposition in a central African tropical mountain forest and Eucalyptus plantation, Forest Ecol. Manage., 326, 109-116, https://doi.org/10.1016/j.foreco.2014.04.015, 2014.

Clark, K. E., West, A. J., Hilton, R. G., Asner, G. P., Quesada, C. A., Silman, M. R., Saatchi, S. S., Farfan-Rios, W., Martin, R. E., Horwath, A. B., Halladay, K., New, M., and Malhi, Y.: Stormtriggered landslides in the Peruvian Andes and implications for topography, carbon cycles, and biodiversity, Earth Surf. Dynam., 4, 47-70, https://doi.org/10.5194/esurf-4-47-2016, 2016.

Clark, K. E., Hilton, R. G., West, A. J., Robles Caceres, A., Gröcke, D. R., Marthews, T. R., Ferguson, R. I., Asner, G. P., New, M., and Malhi, Y.: Erosion of organic carbon from the Andes and its effects on ecosystem carbon dioxide balance, J. Geophys. Res.Biogeo., 122, 449-469, https://doi.org/10.1002/2016JG003615, 2017.

Clark, D. B., Hurtado, J., and Saatchi, S. S.: Tropical Rain Forest Structure, Tree growth and dynamics along a 2700-m elevational transect in Costa Rica, PLoS ONE, 10, e0122905, https://doi.org/10.1371/journal.pone.0122905, 2015.

Clerici, N., Rubiano, K., Abd-Elrahman, A., Posada Hoestettler, J. M., and Escobedo, F. J.: Estimating aboveground biomass and carbon stocks in periurban andean secondary forests using very high resolution imagery, Forests, 7, 138, https://doi.org/10.3390/f7070138, 2016.

Coûteaux, M. M., Sarmiento, L., Bottner, P., Acevedo, D., and Thiéry, J. M.: Decomposition of standard plant material along an altitudinal transect $(65-3968 \mathrm{~m})$ in the tropical Andes, Soil Biol. Biochem., 34, 69-78, https://doi.org/10.1016/S00380717(01)00155-9, 2002.

Cuervo-Robayo, A. P., Ureta, C., Gómez-Albores, M. A., MenesesMosquera, A. K., Téllez-Valdés, O., and Martínez-Meyer, E.: One hundred years of climate change in Mexico, PLoS ONE, 15, e0209808, https://doi.org/10.1371/journal.pone.0209808, 2020.

Culmsee, H., Leuschner, C., Moser, G., and Pitopang, R.: Forest aboveground biomass along an elevational transect in Sulawesi, Indonesia, and the role of Fagaceae in tropical montane rain forests, J. Biogeogr., 37, 960-974, https://doi.org/10.1111/j.1365-2699.2009.02269.x, 2010.

Cuni-Sanchez, A., Pfeifer, M., Marchant, R., Calders, K., Sørensen, C. L., Pompeu, P. L., Lewis, S. L., and Burgess, N. D.: New insights on above ground biomass and forest attributes in tropical montane forests, Forest Ecol. Manage., 399, 235-246, https://doi.org/10.1016/j.foreco.2017.05.030, 2017.

Dalling, J., Heineman, K., González, G., and Ostertag, R.: Geographic, environmental and biotic sources of variation in the nutrient relations of tropical montane forests, J. Trop. Ecol., 32, 368-383, https://doi.org/10.1017/S0266467415000619, 2016.

de la Cruz-Amo, L., Bañares-de-Dios, G., Cala, V., Granzowde la Cerda, I., Espinosa, C. I., Ledo, A., Salinas, N., Macía, M. J., and Cayuela, L.: Trade-offs among aboveground, belowground, and soil organic carbon stocks along altitudinal gradients 
in andean tropical montane Forests, Front. Plant Sci., 11, 106, https://doi.org/10.3389/fpls.2020.00106, 2020.

Dieleman, W. I. J., Venter, M., Ramachandra, A., Krockenberger, A. K., and Bird, M. I.: Soil carbon stocks vary predictably with altitude in tropical forests: Implications for soil carbon storage, Geoderma, 204-205, 59-67, https://doi.org/10.1016/j.geoderma.2013.04.005, 2013.

Dinerstein, E., Olson, D., Joshi, A., Vynne, C., Burgess, N. D., Wikramanayake, E., Hahn, N., Palminteri, S., Hedao, P., Noss, R., Hansen, M., Locke, H., Ellis, E. C., Jones, B., Barber, C. V., Hayes, R., Kormos, C., Martin, V., Crist, E., Sechrest, W., Price, L.. Baillie, J. E. M., Weeden, D., Suckling, K., Davis, C., Sizer, N., Moore, R., Thau, D., Birch, T., Potapov, P., Turubanova, S., Tyukavina, A., Souza, N., Pintea, L., Brito, J. C., Llewellyn, J. A., Miller, A. G., Patzelt, A., Ghazanfar, S. A., Timberlake, J., Klöser, H., Shennan-Farpón, Y., Kindt, R., Barnekow Lilles $\varnothing$, J. P., van Breugel, P., Graudal, L., Voge, M., Al-Al-Shammari, K. F., and Saleem, M.: An Ecoregion-Based Approach to Protecting Half the Terrestrial Realm, Bioscience, 67, 534-545, https://doi.org/10.1093/biosci/bix014, 2017.

Duque, A., Peña, M. A., Cuesta, F., González-Caro, S., Kennedy, P., Phillips, O. L., Calderón-Loor, M., Blundo, C., Carilla, J., Cayola, L., Farfán-Ríos, W., Fuentes, A., Grau, R., Homeier, J., Loza-Rivera, M. I., Malhi, Y., Malizia, A., Malizia, L., MartínezVilla, J. A., Myers, J. A., Osinaga-Acosta, O., Peralvo, M., Pinto, E., Saatchi, S., Silman, M., Tello, J. S., Terán-Valdez, A., and Feeley, K. J.: Mature Andean forests as globally important carbon sinks and future carbon refuges, Nat. Commun., 12, 2138, https://doi.org/10.1038/s41467-021-22459-8, 2021.

Ebeling, A., Meyer, S. T., Abbas, M., Eisenhauer, N., Hillebrand, H., Lange, M., Scherber, C., Voogel, A., Weigelt, A., and Weisser, W. W.: Plant diversity impacts decomposition and herbivory via changes in aboveground arthropods, PLoS ONE, 9, e106529, https://doi.org/10.1371/journal.pone.0106529, 2014.

Eisenhauer, N., Dobies, T. Cesarz, S., Hobbie, S. Meyer, R. Worm, K., and Reich, P.: Plant diversity effects on soil food webs are stronger than those of elevated $\mathrm{CO} 2$ and $\mathrm{N}$ deposition in a longterm grassland experiment, P. Natl. Acad. Sci. USA, 110, 68896894, https://doi.org/10.1073/pnas.1217382110, 2013.

Esquivel, J., Park, B. B., Casanoves, F., Delgado, D., Park, G. E., and Finegan, B.: Altitude and species identity drive leaf litter decomposition rates of ten species on a $2950 \mathrm{~m}$ altitudinal gradient in Neotropical rain forests, Biotropica, 52, 11-21, https://doi.org/10.1111/btp.12730, 2020.

Etter, A. and van Wyngaarden, W.: Patterns of landscape transformation in Colombia, with emphasis in the Andean region, Ambio, 29, 432-439, https://doi.org/10.1579/0044-7447-29.7.432, 2000.

Fahey, T., Sherman, R., and Tanner, E.: Tropical montane cloud forest: Environmental drivers of vegetation structure and ecosystem function, J. Trop. Ecol., 32, 355-367, https://doi.org/10.1017/S0266467415000176, 2016.

Farley, K. A., Kelly E. F., and Hofstede R. G. M.: Soil organic carbon and water retention following conversion of grasslands to pine plantations in the Ecuadorian Andes, Ecosystems, 7, 729739, https://doi.org/10.1007/s10021-004-0047-5, 2004

Farley, K. A., Bremer, L. L., Harden, C. P., and Hartsig, J.: Changes in carbon storage under alternative land uses in biodiverse Andean grasslands: implications for payment for ecosystem ser- vices, Conserv. Lett., 6, 21-27, https://doi.org/10.1111/j.1755263X.2012.00267.x, 2013.

Fehse, J., Hofstede, R., Aguirre, N., Paladines, C., Koijman, A., and Svink, J.: High altitude tropical secondary forests: a competitive carbon sink?, Forest Ecol. Manage., 163, 9-25, https://doi.org/10.1016/S0378-1127(01)00535-7, 2002.

Fernandez, C. W. and Kennedy, P. G.: Revisiting the 'Gadgil effect': do interguild fungal interactions control carbon cycling in forest soils?, New Phytol., 209, 1382-1394, https://doi.org/10.1111/nph.13648, 2015.

Fisher, J. B., Malhi, Y., Torres, I. C., Metcalfe, D. B., van de Weg, M. J., Meir, P., Silva-Espejo, J. E., and Huasco, W. H.: Nutrient limitation in rainforests and cloud forests along a 3,000-m elevation gradient in the Peruvian Andes, Oecologia, 172, 889-902, https://doi.org/10.1007/s00442-012-2522-6, 2013.

Flenley, J. R.: Nature and dynamics of forest savannah boundaries, ultraviolet-B isolation and the altitudinal forest limit, edited by: Furley, P., Ratter, J., and Proctor, J., Chapman and Hall, London, UK, 273-282, ISBN $04124437089780412443701,1992$.

Four, B., Cárdenas, R. E., and Dangles, O.: Traits or habitat? Disentangling predictors of leaf-litter decomposition in Amazonian soils and streams, Ecosphere, 10, e02691, https://doi.org/10.1002/ecs2.2691, 2019.

Fox, J. C., Yosi, C. K., Nimiago, P., Oavika, F., Pokana J. N., Lavong, K., and Keenan R. J.: Assessment of Aboveground Carbon in Primary and Selectively Harvested Tropical Forest in Papua New Guinea, Biotropica, 42, 410-319, https://doi.org/10.1111/j.1744-7429.2009.00617.x, 2010.

Freschet, G. T., Aerts, R., and Cornelissen, J. H. C.: Multiple mechanisms for trait effects on litter decomposition: moving beyond home-field advantage with a new hypothesis, J. Ecol., 100, 619630, https://doi.org/10.1111/j.1365-2745.2011.01943.x, 2012.

Freschet, G. T., Roumet, C., Comas, L. H., Weemstra, M., Bengough, A. G., Rewald, B., Bardgett, R. D., De Deynm G. B., Johnson, D., Klimešová, J., Lukac, M., McCormack, M. L., Meier, I. C., Pagès, L., Poorter, H., Prieto, I., Wurzburger, N., Zadworny, M., Bagniewska-Zadworna, A., Blancaflor, E. B., Brunner, I., Gessler, A., Hobbie, S. E., Iversen, C. M., Mommer, L., Picon-Cochard, C., Postma, J. A., Rose, L., Ryser, P., Scherer-Lorenzen, M., Soudzilovskaia, N. A., Sun, T., ValverdeBarrantes, O. J., Weigelt, A., and York, L. M., and Stokes, A.: Root traits as drivers of plant and ecosystem functioning: current understanding, pitfalls and future research needs, New Phytol., 232, 1123-1158, https://doi.org/10.1111/nph.17072, 2021.

Gebeyehu, G., Soromessa, T., Bekele, T., and Teketay, D.: Carbon stocks and factors affecting their storage in dry Afromontane forests of Awi Zone, northwestern Ethiopia, J. Ecol. Environ., 43, 7, https://doi.org/10.1186/s41610-019-0105-8, 2019.

Geisen, S., Wall, D., and van der Putten, W. H.: Challenges and Opportunities for Soil Biodiversity in the Anthropocene, Curr. Biol., 29, R1036-R1044, https://doi.org/10.1016/j.cub.2019.08.007, 2019.

Gessner, M. O., Swan, C. M., Dang, C. K., McKie, B. G., Bardgett, R. D., Wall, D. H., and Hättenschwiler, S.: Diversity meets decomposition, Trends Ecol. Evol., 5, 372-380, https://doi.org/10.1016/j.tree.2010.01.010, 2010.

Giardina, C. P., Litton, C. M., Crow, S. E., and Asner G. P.: Warming-related increases in soil $\mathrm{CO}_{2}$ efflux are explained by 
increased below-ground carbon flux, Nat. Clim. Change, 4, 822827, https://doi.org/10.1038/NCLIMATE2322, 2014.

Gibbon, A., Silman, M. R., Malhi, Y., Fisher, J. B., Meir, P., Zimmermann, M., Dargie, G. C., Farfan-Rios, W. R., and Garcia, K. C.: Ecosystem carbon storage across the grassland-forest transition in the high Andes of Manu National Park, Peru, Ecosystems, 13, 1097-1111, https://doi.org/10.1007/s10021-010-9376$8,2010$.

Girardin, C. A. J., Malhi, Y., Aragao, L. E. O. C., Mamani, M., Huaraca-Huasco, W., Durand, L., Feeley, K. J., Rapp, J., SilvaEspejo, J. E., Silman, M., Salinas, N., and Whittaker, R. J.: Net primary productivity allocation and cycling of carbon along a tropical forest elevational transect in the Peruvian Andes, Global Change Biol., 16, 3176-3192, https://doi.org/10.1111/j.13652486.2010.02235.x, 2010.

Girardin, C. A. J., Aragão, L. E. O. C., Malhi, Y., HuaracaHuasco, W., Metcalfe, D. B., Durand, L., Mamani, M., Silva-Espejo, J. E., and Whittaker, R. J.: Fine root dynamics along an elevational gradient in tropical Amazonian and Andean forests, Global Biogeochem. Cy., 27, 252-264, https://doi.org/10.1029/2011GB004082, 2013a.

Girardin, C. A. J., Farfan-Rios, W., Garcia, K., Feeley, K. J., Jørgensen, P. M., Araujo Murakami, A., Cayola Pérez, L., Seidel, R., Paniagua, N., Fuentes Claros, A. F., Maldonado, C., Silman, M., Salinas, N., Reynel, C., Neill, D. A., Serrano, M., Caballero, C. J., La Torre Cuadros, M. A., Macía, M. J., Killeen, T. J., and Malhi, Y.: Spatial patterns of aboveground structure, biomass and composition in a network of six Andean elevation transects, Plant. Ecol. Divers., 7, 161-171, https://doi.org/10.1080/17550874.2013.820806, 2013b.

Girardin, C., Malhi, Y., Feeley, K., Rapp, J., Silman, M., Meir, P., Huaraca-Huasco, W., Salinas, N., Mamani, M., SilvaEspejo, J. E., García-Cabrera, K., Farfan-Rios, W., Metcalfe, D. B., Doughty, C. E., and Aragao, L. E. O. C.: Seasonality of above-ground net primary productivity along an Andean altitudinal transect in Peru, J. Trop. Ecol., 30, 503-519, https://doi.org/10.1017/S0266467414000443, 2014a.

Girardin, C. A. J., Silva-Espejo, J. E., Doughty, C. E., HuaracaHuasco, W., Metcalfe, D. B., Durand-Baca, L., Marthews, T. R., Aragao, L. E. O. C., Farfán-Rios, W., García-Cabrera, K., Halladay, K., Fisher, J. B., Galiano-Cabrera, D. F., HuaracaQuispe, L. P., Alzamora-Taype, I., Eguiluz-Mora, L., SalinasRevilla, N., Silman, M. R., Meir, P., and Malhi, Y.: Productivity and carbon allocation in a tropical montane cloud forest in the Peruvian Andes, Plant. Ecol. Divers., 7, 107-123, https://doi.org/10.1080/17550874.2013.820222, 2014b.

Giweta, M.: Role of litter production and its decomposition, and factors affecting the processes in a tropical forest ecosystem: a review, J. Ecol. Environ., 44, 11, https://doi.org/10.1186/s41610020-0151-2, 2020.

González-Jaramillo, V., Fries, A., Zeilinger, J., Homeier, J., Paladines-Benitez, J., and Bendix, J.: Estimation of Above Ground Biomass in a Tropical Mountain Forest in Southern Ecuador Using Airborne LiDAR Data, Remote Sens., 10, 660, https://doi.org/10.3390/rs10050660, 2018.

Graefe, S., Hertel, D., and Leuschner, C.: Fine root dynamics along a 2,000-m elevation transect in South Ecuadorian mountain rainforests, Plant Soil, 313, 155-166, https://doi.org/10.1007/s11104-008-9688-z, 2008a.
Graefe, S., Hertel, D., and Leuschner, C.: Estimating Fine Root Turnover in Tropical Forests along an Elevational Transect using Minirhizotrons, Biotropica, 40, 536-542, https://doi.org/10.1111/j.1744-7429.2008.00419.x, 2008b.

Guillozet, K., Bliss, J. C., and Kelecha, T. S.: Degradation in an Afromontane Forest in Highland Ethiopia, 1969-2010, SmallScale For., 14, 121-137, https://doi.org/10.1007/s11842-0149277-3, 2015.

Gurdak, D. J., Aragao, L. E. O. C., Rozas-Dávila, A., Huasco, W. H., Cabrera, K. G., Doughty, C. E., Farfan-Rios, W., SilvaEspejo, J. E., Metcalfe, D. B., Silman, M. R., and Malhi, Y.: Assessing above-ground woody debris dynamics along a gradient of elevation in Amazonian cloud forests in Peru: balancing aboveground inputs and respiration outputs, Plant. Ecol. Divers., 7, 143-160, https://doi.org/10.1080/17550874.2013.818073, 2014.

Hawlena D., Strickland, M. S., Bradford, M. A., and Schmitz, O. J.: Fear of predation slows plant-litter decomposition, Science, 336, 1434-1438, https://doi.org/10.1126/science.1220097, 2012.

Heitkamp, F., Sylvester, S. P., Kessler, M., Sylvester, M. D. P. V., and Jungkunst, H. F. Inaccessible Andean sites reveal humaninduced weathering in grazed soils, Prog. Phys. Geogr., 38, 576601, https://doi.org/10.1177/0309133314544918, 2014.

Hobbie, S.: Interactions between Litter Lignin and Nitrogenitter Lignin and Soil Nitrogen Availability during Leaf Litter Decomposition in a Hawaiian Montane Forest, Ecosystems, 3, 484-494, https://doi.org/10.1007/s100210000042, 2000.

Homeier, J. and Leuschner, C.: Factors controlling the productivity of tropical Andean forests: Climate and soil are more important than tree diversity, Biogeosciences, 18, 1525-1541, https://doi.org/10.5194/bg-18-1525-2021, 2020.

Homeier, J., Breckle, S. W., Günter, S., Rollenbeck, R. T., and Leuschner, C.: Tree Diversity, Forest Structure and Productivity along Altitudinal and Topographical Gradients in a SpeciesRich Ecuadorian Montane Rain Forest, Biotropica, 42, 1405148, https://doi.org/10.1111/j.1744-7429.2009.00547.x, 2010.

Homeier, J., Hertel, D., Camenzind, T., Cumbicus, N. L., Maraun, Guntars, M., Martinson, O., Nohemy-Poma, L., Rillig, M. C., Sandmann, D., Scheu, S., Veldkamp, E., Wilcke, W. Wullaert, H., and Leuschner, C.: Tropical Andean Forests Are Highly Susceptible to Nutrient Inputs - Rapid Effects of Experimental N and P Addition to an Ecuadorian Montane Forest, PLoS ONE, 7, e47128, https://doi.org/10.1371/journal.pone.0047128, 2012.

Hurtado-Martilleti, A. B., Echeverry-Galvis, M. A., SalgadoNegret, B., Muñoz, J. C., Posada, J. M., and Norden, N.: Little trace of floristic homogenization in peri-urban Andean secondary forests despite high anthropogenic transformation, J. Ecol., 109, 1468-1478, 2021.

Illig, J., Schatz, H., Scheu, S., and Maraun, M.: Decomposition and colonization by micro-arthropods of two litter types in a tropical montane rain forest in southern Ecuador, J. Trop. Ecol., 24, 157167, https://doi.org/10.1017/S0266467407004750, 2008.

IPCC: Climate change: Impacts, adaptation and vulnerability. Summary for policy makers, Cambridge University Press, Cambridge, UK and New York, USA, 34 pp., https://doi.org/10.1016/j.renene.2009.11.012, 2014.

Juntahum, S., Jongrungklang, N., Kaewpradit, W., Lumyong, S., and Boonlue, S.: Impact of Arbuscular Mycorrhizal Fungi on Growth and Productivity of Sugarcane Under Field Conditions, 
Sugar Tech., 22, 451-459, https://doi.org/10.1007/s12355-01900784-z, 2020.

Kitayama, K. and Aiba, S.: Ecosystem structure and productivity of tropical rain forests along altitudinal gradients with contrasting soil phosphorus pools on Mount Kinabalu, Borneo, J. Ecol., 90, 37-51, https://doi.org/10.1046/j.0022-0477.2001.00634.x, 2002.

Kitayama, K., Majalap-Lee, N., and Aiba, S.: Soil phosphorus fractionation and phosphorus-use efficiencies of tropical rainforests along altitudinal gradients of Mount Kinabalu, Borneo, Oecologia, 123, 342-349, https://doi.org/10.1007/s004420051020, 2000

Koide, R. T. and Wu, T.: Ectomycorrhizas and retarded decomposition in a Pinus resinosa plantation, New Phytol., 158, 401-407, https://doi.org/10.1046/j.1469-8137.2003.00732.x, 2003.

Körner, C.: The use of 'altitude' in ecological research, Trends Ecol. Evol., 22, 569-574, https://doi.org/10.1016/j.tree.2007.09.006, 2007.

Körner, C. and Sphen, E.: A Humboldtian view of mountains, Science, 365, 1061, https://doi.org/10.1126/science.aaz4161, 2019.

Körner, C., Paulsen, J., and Spehn, E. M.: A definition of mountains and their bioclimatic belts for global comparisons of biodiversity data, Alp. Bot., 121, 73, https://doi.org/10.1007/s00035011-0094-4, 2011.

Kübler, D., Hildebrandt, P., Günter, S., Stimm, B., Weber, M., Muñoz, J., Cabrera, O., Zeilinger, J., Silva, B., and Mosandl, R.: Effects of silvicultural treatments and topography on individual tree growth in a tropical mountain forest in Ecuador, Forest Ecol. Manage., 457, 117726, https://doi.org/10.1016/j.foreco.2019.117726, 2020.

Lemenih, M. and Itanna, F.: Soil carbon stocks and turnovers in various vegetation types and arable lands along an elevation gradient in southern Ethiopia, Geoderma, 123, 177-188, https://doi.org/10.1016/j.geoderma.2004.02.004, 2004.

León, J. D., González, M. I., and Gallardo, J. F.: Ciclos biogeoquímicos en bosques naturales y plantaciones de coníferas en ecosistemas de alta montaña de Colombia, Rev. Biol. Trop., 59, 1883-1894, 2011.

Leuschner, C., Moser, G., Bertsch, c., Röderstein, M., and Hertel, D.: Large altitudinal increase in tree root/shoot ratio in tropical mountain forests of Ecuador, Basic Appl. Ecol., 8, 219-230, https://doi.org/10.1016/j.baae.2006.02.004, 2007.

Leuschner, C., Zach, A., Moser, G., Homeier, J., Graefe, S., Hertel, D., Wittich, B., Soethe, N., Iost, S., Röderstein, M., Horna, V., and Wolf, K.,:The Carbon Balance of Tropical Mountain Forests Along an Altitudinal Transect, in: Ecosystem Services, Biodiversity and Environmental Change in a Tropical Mountain Ecosystem of South Ecuador, edited by: Bendix, J., Beck, E., Bräuning, A., Makeschin, F., Mosandl, R., and Scheu, S., Springer, Berlin, Heidelberg, Germany, 117-139, https://doi.org/10.1007/978-3642-38137-9_10, 2013.

Lin, G., McCormack, L., Ma, C., and Guo, D.: Similar below-ground carbon cycling dynamics but contrasting modes of nitrogen cycling between arbuscular mycorrhizal and ectomycorrhizal forests, New Phytol., 213, 1440-1451, https://doi.org/10.1111/nph.14206, 2017.

Litton, C. M., Giardina, C. P., Albano, J. K., Long, M. S., and Asner, G. P.: The magnitude and variability of soil-surface $\mathrm{CO}_{2}$ efflux increase with temperature in Hawaiian tropical montane wet forests, Soil Biol. Biochem., 43, 2315-2323, https://doi.org/10.1016/j.soilbio.2011.08.004, 2011.

Litton, C. M., Giardina, C. P., Freeman, K. R., Selmants, P. C., and Sparks, J. P.: Impact of Mean Annual Temperature on Nutrient Availability in a Tropical Montane Wet Forest, Front. Plant Sci., 11, 784, https://doi.org/10.3389/fpls.2020.00784, 2020.

Liu, H., Li, L., Han, X., Huang, J., Sun, J., and Wang, H: Respiratory substrate availability plays a crucial role in the response of soil respiration to environmental factors, Appl. Soil Ecol., 32, 284-292, https://doi.org/10.1016/j.apsoil.2005.08.001, 2006.

Loreau, M., Naeem, S., Inchausti, P., Bengtsson, J., Grime, J. P., Hector, A., Hooper, D. U., Huston, M. A., Raffaelli, D., Schmid, B., Tilman, D., and Wardle, D. A.: Biodiversity and ecosystem functioning: current knowledge and future challenges, Science, 294, 5543, https://doi.org/10.1126/science.1064088, 2001.

Malhi, Y., Silman, M., Salinas, N., Bush, M., Meir, P., and Saatchi, S.: Introduction: elevation gradients in the tropics: laboratories for ecosystem ecology and global change research, Global Change Biol., 16, 3171-3175, https://doi.org/10.1111/j.13652486.2010.02323.x, 2010.

Malhi, Y., Doughty, C., and Galbraith, D.: The allocation of ecosystem net primary productivity in tropical forests, Philos. T. Roy. Soc. Lond. B, 366, 3225-3245, https://doi.org/10.1098/rstb.2011.0062, 2011.

Malhi, Y., Girardin, C. A., Goldsmith, G. R., Doughty, C. E., Salinas, N., Metcalfe, D. B., Huaraca-Huasco, W., Silva-Espejo, J. E., Del Aguilla-Pasquell, J., Farfán-Amézquita, F., Aragão, L. E. O. C., Guerrieri, R., Ishida, F. Y., Bahar, N. H., Farfan-Rios, W., Phillips, O. L., Meir, P., and Silman, M.: The variation of productivity and its allocation along a tropical elevation gradient: a whole carbon budget perspective, New Phytol., 214, 1019-1032, https://doi.org/10.1111/nph.14189, 2017.

Marian, F., Sandmann, D., Krashevska, V., Maraun, M., and Scheu, S.: Leaf and root litter decomposition is discontinued at high altitude tropical montane rainforests contributing to carbon sequestration, Ecol. Evol., 7, 6432-6443, https://doi.org/10.1002/ece3.3189, 2017.

Marian, F., Sandmann, D., Krashevska, V., Maraun, M., and Scheu, S.: Altitude and decomposition stage rather than litter origin structure soil microarthropod communities in tropical montane rainforests, Soil Biol. Biochem., 125, 263-274, https://doi.org/10.1016/j.soilbio.2018.07.017, 2018.

Marthews, T. R., Malhi, Y., Girardin, C. A., Silva-Espejo, J. E., Aragão, L. E. O. C., Metcalfe D. B., Rapp, J. M., Mercado, L. M., Fisher, R. A., Galbraith, D. R., Fisher, J. B., SalinasRevilla, N., Friend, A. D., Restrepo-Coupe, N., and Williams, R. J.: Simulating forest productivity along a neotropical elevational transect: temperature variation and carbon use efficiency, Global Change Biol., 18, 2882-2898, https://doi.org/10.1111/j.13652486.2012.02728.x, 2012.

McNaughton, S., Oesterheld, M., Frank, D., and Williams, K. J.: Ecosystem-level patterns of primary productivity and herbivory in terrestrial habitats, Nature, 341, 142-144, https://doi.org/10.1038/341142a0, 1989.

Melo, F. P., Arroyo-Rodríguez, V., Fahrig, L., Martínez-Ramos, M., and Tabarelli, M.: On the hope for biodiversityfriendly tropical landscapes, Trends Ecol. Evol., 28, 462-468, https://doi.org/10.1016/j.tree.2013.01.001, 2013. 
Metcalfe, D. B., Asner, G. P., Martin, R. E., Silva-Espejo, J. E., Huasco, W. H., Farfán-Amézquita, F. F., Carranza-Jimenez, L., Galiano-Cabrera, D. F., Baca, L. D., Sinca, F., Huaraca-Quispe, L. P., Taype, I. A., Mora, L. E., Dávila, A. R., Solórzano, M. M., Puma-Vilca, B. L., Laupa-Román, J. M., Guerra-Bustios, P. C,, Revilla, N. S., Tupayachi, R., Girardin. C. A., Doughty, C. E., and Malhi, Y.: Herbivory makes major contributions to ecosystem carbon and nutrient cycling in tropical forests, Ecol. Lett., 17, 324-332, https://doi.org/10.1111/ele.12233, 2014.

Moser, G., Hertel, D., and Leuschner, C.: Altitudinal Change in LAI and Stand Leaf Biomass in Tropical Montane Forests: a Transect Study in Ecuador and a Pan-Tropical Meta-Analysis, Ecosystems, 10, 924-935, https://doi.org/10.1007/s10021-007-9063-6, 2007.

Moser, G., Röderstein, M., Soethe, N., Hertel, D., and Leuschner C.: Altitudinal Changes in Stand Structure and Biomass Allocation of Tropical Mountain Forests in Relation to Microclimate and Soil Chemistry, in: Gradients in a Tropical Mountain Ecosystem of Ecuador, edited by: Beck, E., Bendix, J., Kottke, I., Makeschin, F., and Mosandl, R., Springer, Berlin, Heidelberg, Germany, 229-242, https://doi.org/10.1007/978-3-54073526-7_22, 2008.

Moser, G., Leuschner, C., Röderstein, M., Graefe, S., Soethe, N., and Hertel, D.: Biomass and productivity of fine and coarse roots in five tropical mountain forests stands along an altitudinal transect in southern Ecuador, Plant Ecol. Divers., 3, 151-164, https://doi.org/10.1080/17550874.2010.517788, 2010.

Moser, G., Leuschner, C., Hertel, D., Graefe, S., Soethe, N., and Iost, S.: Elevation effects on the carbon budget of tropical mountain forests ( $S$ Ecuador): the role of the belowground compartment, Global Change Biol., 17, 2211-2226, https://doi.org/10.1111/j.1365-2486.2010.02367.x, 2011.

Murcia-Rodríguez, M. A. and Ochoa-Reyes, M. P.: Respiración del suelo en una comunidad sucesional de pastizal del bosque altoandino en la cuenca del río Pamplonita, Colombia, Caldasia, 30, 337-353, 2008.

Murcia-Rodríguez, M. A., Ochoa-Reyes, M. P., and Poveda-Gómez, F. E.: Respiración del suelo y caída de hojarasca en el matorral del bosque altoandino (cuenca del río Pamplonita, Colombia), Caldasia, 34, 165-185, 2012.

Nierop, K. G. J., Tonneijck, F. H., Jansen, B., and Verstraten, J. M.: Organic Matter in Volcanic Ash Soils under Forest and Páramo along an Ecuadorian Altitudinal Transect, Soil Sci. Soc. Am. J., 71, 1119-1127, https://doi.org/10.2136/sssaj2006.0322, 2007.

NOAA: National Centers for Environmental Information, State of the Climate: Global Climate Report for Annual 2019, available at: https://www.ncdc.noaa.gov/sotc/global/201913, last access: 16 January 2021.

Nottingham, A. T., Ccahuana, A. J. Q., and Meir, P.: Soil properties in tropical montane cloud forests influence estimates of soil $\mathrm{CO}_{2}$ efflux, Agr. Forest Meteorol., 166-167, 215-220, https://doi.org/10.1016/j.agrformet.2012.08.008, 2012.

Nottingham, A. T., Fierer N., Turner, B. L., Whitaker, K., Ostle, N. J., McNamara, N. P., Bardgett, R. D., Leff, J. W., Salinas, N., Silman, M. R., Kruuk, L. E. B., and Mei, P.: Microbes follow Humboldt: temperature drives plant and soil microbial diversity patterns from the Amazon to the Andes, Ecology, 99, 2455-2466, https://doi.org/10.1002/ecy.2482, 2018.
Nyirambangutse, B., Zibera, E., Uwizeye, F. K., Nsabimana, D., Bizuru, E., Pleijel, H., Uddling, J., and Wallin, G.: Carbon stocks and dynamics at different successional stages in an Afromontane tropical forest, Biogeosciences, 14, 1285-1303, https://doi.org/10.5194/bg-14-1285-2017, 2017.

Oliveras, I., Girardin, C., Doughty, C. E., Cahuana, N., Arenas, C. E., Oliver, V., Huasco, W. H., and Malhi, Y.: Andean grasslands are as productive as tropical cloud forests, Environ. Res. Lett., 9, 115011, https://doi.org/10.1088/1748-9326/9/11/115011, 2014.

Olson, D. M. and Dinerstein, E.: The Global 200: Priority ecoregions for global conservation, Ann. Missouri Bot. Gard., 89, 199-224, https://doi.org/10.2307/3298564, 2002.

Olson, D. M., Dinerstein, E., Wikramanayake, E. D., Burgess, N. D., Powell, G. V. N., Underwood, E. C., D’amico, J. A., Itoua, I., Strand, H. E., Morrison, J. C., Loucks, J. C. Allnutt, T. F., Ricketts, T. H., Kura, Y., Lamoreux, J. F.,. Wettengel, W. W., Hedao, P., and Kassem, K. R.: Terrestrial Ecoregions of the World: A New Map of Life on Earth: A new global map of terrestrial ecoregions provides an innovative tool for conserving biodiversity, BioScience, 51, 11, 933-938, https://doi.org/10.1641/00063568(2001)051[0933:TEOTWA]2.0.CO;2, 2001.

Palace, M., Keller, M., Asner, G. P., Silva, J. N. M., and Passos, C.: Necromass in undisturbed and logged forests in the Brazilian Amazon, Forest Ecol. Manage., 238, 309-318, https://doi.org/10.1016/j.foreco.2006.10.026, 2007.

Pearse, I. S., Cobb, R. C., and Karban, R.: The phenologysubstrate-match hypothesis explains decomposition rates of evergreen and deciduous oak leaves, J. Ecol., 102, 28-35, https://doi.org/10.1111/1365-2745.12182, 2014.

Peña, E. J., Sandoval, H., Zuñiga, O., and Torres, M.: Estimates of Carbon Reservoirs in High-Altitude Wetlands in the Colombian Andes, J. Agricult. Rural Dev. Trop. Subtrop., 110, 115126, 2010.

Phillips, J., Duque, A. Scott, C., Wayson, C., Galindo, G., Cabrera, E., Chave, J., Peña, M., Álvarez, E., Cárdenas, D., Duivenvoorden, J., Hildebrand, P., Stevenson, P., Ramírez, S., and Yepes, A.: Live aboveground carbon stocks in natural forests of Colombia, Forest Ecol. Manage., 374, 119-128, https://doi.org/10.1016/j.foreco.2016.05.009, 2016.

Phillips, J., Ramirez, S., Wayson, C., and Duque, A.: Differences in carbon stocks along an elevational gradient in tropical mountain forests of Colombia, Biotropica, 51, 490-499, https://doi.org/10.1111/btp.12675, 2019.

Pierick, K., Leuschner, C., and Homeier, J.: Topography as a factor driving small-scale variation in tree fine root traits and root functional diversity in a species-rich tropical montane forest, New Phytol., 30, 129-138, https://doi.org/10.1111/nph.17136, 2021.

Pinos, J., Studholme, A., Carabajo, A., and Gracia, C.: Leaf Litterfall and Decomposition of Polylepis reticulata in the Treeline of the Ecuadorian Andes, Mount. Res. Dev., 37, 87-96, https://doi.org/10.1659/MRD-JOURNAL-D-16-00004.1, 2017.

Pizano, C., Kitajima, K., Graham, J. H., and Mangan, S. A.: Negative plant-soil feedbacks are stronger in agricultural habitats than in forest fragments in the tropical Andes, Ecology, 100, e02850, https://doi.org/10.1002/ecy.2850, 2019.

Ponette-González, A. G., Ewing, H. A., Fry, M., and Young, K. R.: Soil and fine root chemistry at a tropical Andean timberline, Catena, 137, 350-359, https://doi.org/10.1016/j.catena.2015.10.014, 2016. 
Poorter, L., van der Sande, M. T., Thompson, J., Arets, E. J. M. M., Alarcón, A., Álvarez-Sánchez, J., Ascarrunz, N., Balvanera, P., Barajas-Guzmán, G., Boit, A., Bongers, F., Carvalho, F. A., Casanoves, F., Cornejo-Tenorio, G., Costa, F. R. C., de Castilho, C. V., Duivenvoorden, J. F., Dutrieux, L. P., Enquist, B. J., Fernández-Méndez, F., Finegan, B., Gormley, L. H. L., Healey, J. R., Hoosbeek, M. R., Ibarra-Manríquez, G., Junqueira, A. B., Levis, C., Licona, J. C., Lisboa, L. S., Magnusson, W. E., Martínez-Ramos, M., Martínez-Yrizar, A., Martorano, L. G., Maskell, L. Mazzei C. L., Meave, J. A., Mora, F., Muñoz, R., Nytch, C., Pansonato, M. P., Parr, T. W., Paz, H., Pérez-García, E. A., Rentería, L. Y., Rodríguez-Velazquez, J., Rozendaal, D. M. A., Ruschel, A. R., Sakschewski, B., SalgadoNegret, B., Schietti, J., Simões, M., Sinclair, F. L., Souza, P. F., Souza, F. C., Stropp, J., ter Steege, H., Swenson, N. G., Thonicke, K., Toledo, M., Uriarte, M., van der Hout, P., Walker, P., Zamora, N., and Peña-Claros, M.: Diversity enhances carbon storage in tropical forests, Global Ecol. Biogeogr., 24, 1314 1328, https://doi.org/10.1111/geb.12364, 2015.

Powers, J. S., Montgomery, R. M., Adair, C. E., Brealey, F. Q., De Walt, S. J., Saarah, J., Castanho, C. T., Chave, J., Deiniert, E., Ganzhonr, J. U., Gilbert, M. E., Gonzalez-Iturbe, J. A., Bunyavejchewin, S., Grau, H. R., Harms, K. E., Hiremath, A., IriarteVivar, S., Manzane, E., De Oliveira, A. A., Poorter, L., Ramanamanjato, J. B., Salk, C., Varela, A., Weiblen, G. D., and Lerday, M. T.: Decomposition in tropical forests: A pan-tropical study of the effects of litter type, litter placement and mesofaunal exclusion across a precipitation gradient, J. Ecol., 97, 801-811, https://doi.org/10.1111/j.1365-2745.2009.01515.x, 2009.

Quichimbo, P., Jiménez, L., Veintimilla, D., Tischer, A., Günter, S., Mosandl, R., and Hamer, U.: Forest Site Classification in the Southern Andean Region of Ecuador: A Case Study of Pine Plantations to Collect a Base of Soil Attributes, Forests, 8, 473, https://doi.org/10.3390/f8120473, 2017.

Rahbek, C., Borregaard, M. K., Colwell, R. K., Dalsgaard, B., Holt, B. G., Morueta-Holme, N., Nogues-Bravo, D., Whittaker, R. J., and Fjeldså, J.: Humboldt's enigma: What causes global patterns of mountain biodiversity?, Science, 365, 1108-1113, https://doi.org/10.1126/science.aax0149, 2019.

Román-Cuesta, R. M., Salinas, N., Asbjornsen, H., Oliveras, I., Huaman, V., Gutiérrez, Y., Puelles, L., Kala, J., Yabar, D., Rojas, M., Astete, R., Jordán, D. Y., Silman, M., Mosandl, R., Weber, M., Stimm, B., Günter, S., Knoke, T., and Malhi, Y.: Implications of fires on carbon budgets in Andean cloud montane forest: The importance of peat soils and tree resprouting, Forest Ecol. Manage., 261, 1987-1997, https://doi.org/10.1016/j.foreco.2011.02.025, 2011.

Raich, J. W., Russell, A. E., Kitayama, K., Parton, W. J., and Vitousek, P. M.: Temperature influences carbon accumulation in moist tropical forests, Ecology, 87, 76-87, https://doi.org/10.1890/05-0023, 2006.

Ramírez-Correa, J. A., Zapata-Duque, C. M., León-Peláez, J. D., and González-Hernández, M. I.: Caída de hojarasca y retorno de nutrientes en bosques montanos andinos de piedras blancas, Antioquia, Colombia, Interciencia, 32, 303-311, 2007.

Ramos Scharrón, C. E., Castellanos, E. J., and Restrepo, C.: The transfer of modern organic carbon by landslide activity in tropical montane ecosystems, J. Geophys. Res., 117, G03016, https://doi.org/10.1029/2011JG001838, 2012.
Rapp, J. M., Silman, M. R., Clark, J. S., Girardin, C. A., Galiano, D., and Tito, R.: Intra- and interspecific tree growth across a long altitudinal gradient in the Peruvian Andes, Ecology, 93, 20612072, https://doi.org/10.1890/11-1725.1, 2012.

Rawat, M., Arunachalam, K., and Arunachalam, A.: Plant functional traits and carbon accumulation in forest, Clim. Change Environ. Sustainabil., 3, 1-12, https://doi.org/10.5958/2320642X.2015.00001.0, 2015.

Ristok, C., Leppert, K. N., Scherer-Lorenzen, M., Niklaus, P. A., and Bruelheide, H.: Soil macrofauna and leaf functional traits drive the decomposition of secondary metabolites in leaf litter, Soil Biol. Biochem., 135, 429-437, https://doi.org/10.1016/j.soilbio.2019.06.007, 2019.

Röderstein, M., Hertel, D., and Leuschner, C.: Above- and below-ground litter production in three tropical montane forests in southern Ecuador, J. Trop. Ecol., 21, 483-492, https://doi.org/10.1017/S026646740500249X, 2005.

Rodríguez-Alarcón, S., Rodríguez-Eraso, N., Pineda-Rincón, I., and López-Camacho, R.: Effects of fragmentation on functional diversity associated with aboveground biomass in a high Andean forest in Colombia, Landscape Ecol., 33, 1851-1864, https://doi.org/10.1007/s10980-018-0719-8, 2018.

Román-Cuesta, R. M., Salinas, N., Asbjornsen, H., Oliveras, I., Huaman, V., Gutiérrez, Y., Puelles, L., Kala, J., Yabar, D., Rojas, M., Astete, R., Jordán, D. Y., Silman, M., Mosandl, R., Weber, M., Stimm, B., Günter, S., Knoke, T., and Malhi, Y.: Implications of fires on carbon budgets in Andean cloud montane forest: The importance of peat soils and tree resprouting, Forest Ecol. Manage., 261, 1987-1997, https://doi.org/10.1016/j.foreco.2011.02.025, 2011.

Romero-Torres, M. and Varela-Ramírez, A.: Efecto de borde sobre el proceso de descomposición de hojarasca en bosque nublado, Acta Biol. Colomb., 16, 155-174, 2011.

Rosero, J., Vélez, J., Burbano, H., and Ordóñez, H.: Cuantificación de la respiración y biomasa microbiana en Andisoles del sur de Colombia, Agro Sur, 47, 15-25, https://doi.org/10.4206/agrosur.2019.v47n3-03, 2020.

Rozendaal, D. M. A., Bongers, F., Aide, T. M., Alvarez-Dávila, E., Ascarrunz, N., Balvanera, P., Becknell, J. M., Bentos, T. V., Brancalion, P. H. S., Cabral, G. A. L., Calvo-Rodriguez, S., Chave, J., César, R. G., Chazdon, R. L., Condit, R., Dallinga, J. S., de Almeida-Cortez, J. S., de Jong, B., de Oliveira, A., Denslow, J. S., Dent, D. H., DeWalt, S. J., Dupuy, J. M., Durán, S. M., Dutrieux, L. P., Espírito-Santo, M. M., Fandino, M. C., Fernandes, G. W., Finegan, B., García, H., Gonzalez, N., Moser, V. G., Hall, J. S., Hernández-Stefanoni, J. L., Hubbell, S., Jakovac, C. C., Hernández, A. J., Junqueira, A. B., Kennard, D., Larpin, D., Letcher, S. G., Licona, J. C., LebrijaTrejos, E., Marín-Spiotta, E., Martínez-Ramos, M., Massoca, P. E. S., Meave, J. A., Mesquita, R. C. G., Mora, F., Müller, S. C., Muñoz, R., de Oliveira Neto, S. N., Norden, N., Nunes, Y. R. F., Ochoa-Gaona, S., Ortiz-Malavassi, E., Ostertag, R., Peña-Claros, M., Pérez-García, E. A., Piotto, D., Powers, J. S., Aguilar-Cano, J., Rodriguez-Buritica, S., Rodríguez-Velázquez, J., Romero-Romero, M. A., Ruíz, J., Sanchez-Azofeifa, A., de Almeida, A. S., Silver, W. L., Schwartz, N. B., Thomas, W. W., Toledo, M., Uriarte, M., de Sá Sampaio, E. V., van Breugel, M., van der Wal, H., Martins, S. V., Veloso, M. D. M., Vester, H. F. M., Vicentini, A., Vieira, I. C. G., Villa, P., Williamson, G. B., 
Zanini, K. J., Zimmerman, J., and Poorter, L.: Biodiversity recovery of Neotropical secondary forests, Sci. Adv., 6, eaau3114, https://doi.org/10.1126/sciadv.aau3114, 2019.

Rubiano, K., Clerici, N., Norden, N., and Etter, A.: Secondary forest and shrubland dynamics in a highly transformed landscape in the Northern Andes of Colombia (1985-2015), Forests, 8, 1-17, https://doi.org/10.3390/f8060216, 2017.

Sala, O. E., Chapin, F. S., Armesto, J. J., Berlow, E., Bloomfield, J., Dirzo, R., Huber-Sanwald, E., Huenneke, L. F., Jackson, R. B., Kinzig, A., Leemans, R., Lodge, D. M., Mooney, H. A., Oesterheld, M., Poff, N. L., Sykes, M. T., Walker, B. H., Walker, M., and Wall, D. H.: Global biodiversity scenarios for the year 2100, Science, 287, 1770-1774, https://doi.org/10.1126/science.287.5459.1770, 2000.

Salinas, N., Malhi, Y., Meir, P., Silman, M., Roman-Cuesta, R., Huaman, J., Salinas, D., Huaman, V., Gibaja, A., Mamani, M., and Farfan, F.: The sensitivity of tropical leaf litter decomposition to temperature: results from a large-scale leaf translocation experiment along an elevation gradient in Peruvian forests, New Phytol., 189, 967-977, https://doi.org/10.1111/j.14698137.2010.03521.x, 2011.

Schawe, M., Glatzel, S., and Gerold, G.: Soil development along an altitudinal transect in a Bolivian tropical montane rainforest: Podzolization vs. hydromorphy, Catena, 69, 83-90, https://doi.org/10.1016/j.catena.2006.04.023, 2007.

Schuur, E.: The Effect of Water on Decomposition Dynamics in Mesic to Wet Hawaiian Montane Forests, Ecosystems, 4, 259273, https://doi.org/10.1007/s10021-001-0008-1, 2001.

Schuur, E. A. and Matson, P. A.: Net primary productivity and nutrient cycling across a mesic to wet precipitation gradient in Hawaiian montane forest, Oecologia, 128, 431-442, https://doi.org/10.1007/s004420100671, 2001.

Scowcroft, P. G., Turner, D. R., and Vitousek, P. M.: Decomposition of Metrosideros polymorpha leaf litter along elevational gradients in Hawaii, Global Change Biol., 6, 73-85, https://doi.org/10.1046/j.1365-2486.2000.00282.x, 2000.

Segnini, A., Posadas, A., Quiroz, R., Milori, D. M. B. P., Vaz, C. M. P., and Martin-Neto, L.: Soil carbon stocks and stability across an altitudinal gradient in southern Perú, J. Soil Water Conserv., 66, 213-220, https://doi.org/10.2489/jswc.66.4.213, 2011.

Selmants, P. C., Litton, C. M., Giardina, C. P., and Asner, G. P.: Ecosystem carbon storage does not vary with mean annual temperature in Hawaiian tropical montane wet forests, Global Change Biol., 20, 2927-2937, https://doi.org/10.1111/gcb.12636, 2014.

Selmants, P. C., Adair, K. L., Litton, C. M., Giardina, C. P., and Schwartz, E.: Increases in mean annual temperature do not alter soil bacterial community structure in tropical montane wet forests, Ecosphere, 7, e01296, https://doi.org/10.1002/ecs2.1296, 2016.

Seyfried, H., Worrier, G., Uhlig, D., Kohler, I., and Calvo, C.: Introducción a la geología y morfología de los andes en el norte de Chile, Chungará (Arica), 30, 7-39, https://doi.org/10.4067/S0717-73561998000100002, 1998.

Shirima, D. D. M., Totland, O., Munishi, P. K. T., and Moe, S. R.: Relationships between tree species richness, evenness and aboveground carbon storage in montane forests and miombo woodlands of Tanzania, Basic Appl. Ecol., 16, 239-249, https://doi.org/10.1016/j.baae.2014.11.008, 2015.
Simegn, T. Y. and Soromessa, T.: Carbon Stock Variations Along Altitudinal and Slope Gradient in the Forest Belt of Simen Mountains National Park, Ethiopia, Am. J. Environ. Prot., 4, 199-201, https://doi.org/10.11648/j.ajep.20150404.15, 2015.

Soethe, N., Lehmann, J., and Engels, C.: The Vertical Pattern of Rooting and Nutrient Uptake at Different Altitudes of a South Ecuadorian Montane Forest, Plant Soil, 286, 287-299, https://doi.org/10.1007/s11104-006-9044-0, 2006.

Soethe, N., Lehmann, J., and Engels, C.: Carbon and nutrient stocks in roots of forests at different altitudes in the Ecuadorian Andes, J. Trop. Ecol., 23, 319-328, https://doi.org/10.1017/S0266467407004002, 2007.

Soethe, N., Lehmann, J., and Engels, C.: Nutrient availability at different altitudes in a tropical montane forest in Ecuador, J. Trop. Ecol., 24, 397-406, https://doi.org/10.1017/S026646740800504X, 2008.

Spracklen, D. V. and Righelato, R.: Tropical montane forests are a larger than expected global carbon store, Biogeosciences, 11, 2741-2754, https://doi.org/10.5194/bg-11-2741-2014, 2014.

Spracklen, D. V. and Righelato, R.: Carbon storage and sequestration of re-growing montane forests in southern Ecuador, Forest Ecol. Manage., 364, 139-144, https://doi.org/10.1016/j.foreco.2016.01.001, 2016.

Suárez, R. E. and Medina, G.: Vegetation Structure and Soil Properties in Ecuadorian Páramo Grasslands with Different Histories of Burning and Grazing, Arct. Antarct. Alp. Res., 33, 158-164, https://doi.org/10.2307/1552216, 2001.

Sugden, A.: The montane vegetation and flora of margarita island, Venezuela, J. Arnold Arbor., 67, 187-232, 1986.

Taddese, F. H., Asrat, Z., Burud, I., Gobakken, T., Ørka, H. O., Dick, Ø. B., and Næsset, E.: Use of Remotely Sensed Data to Enhance Estimation of Aboveground Biomass for the Dry Afromontane Forest in South-Central Ethiopia. Remote Sens., 12, 3335, https://doi.org/10.3390/rs12203335, 2020.

Thakur, M. P. and Geisen, S.: Trophic Regulations of the Soil Microbiome, Trends Microbiol., 9, 771-780, https://doi.org/10.1016/j.tim.2019.04.008, 2019.

Tilman, D., Reich, P. B., and Isbell, F.: Biodiversity impacts ecosystem productivity as much as resources, disturbance, or herbivory, P. Natl. Acad. Sci. USA, 109, 10394-10397, https://doi.org/10.1073/pnas.1208240109, 2012.

Tonneijck, F. H. and Jongmans, A. G.: The influence of bioturbation on the vertical distribution of soil organic matter in volcanic ash soils: a case study in northern Ecuador, Eur. J. Soil Sci., 59, 1063-1075, https://doi.org/10.1111/j.13652389.2008.01061.x, 2008.

Tonneijck, F. H., Jansen, B., Nierop, K. G. J., Verstraten, J. M., Sevink, J., and De Lange, L.: Towards understanding of carbon stocks and stabilization in volcanic ash soils in natural Andean ecosystems of northern Ecuador, Eur. J. Soil Sci., 61, 392-405, https://doi.org/10.1111/j.1365-2389.2010.01241.x, 2010.

Unger, M., Homeier, J., and Leuschner, C.: Effects of soil chemistry on tropical forest biomass and productivity at different elevations in the equatorial Andes, Oecologia, 170, 263-274, https://doi.org/10.1007/s00442-012-2295-y, 2012.

Urgiles, N., Loján, P., Aguirre, N., Blaschke, H., Günter, B., and Kottke, I.: Application of mycorrhizal roots improves growth of tropical tree seedlings in the nursery: a step towards reforestation 
with native species in the Andes of Ecuador, New Forests, 38, 229-239, https://doi.org/10.1007/s11056-009-9143-x, 2009.

Varela, A., Barriga, P., and Ahumada, J.: Comparación de factores abióticos relacionados con la descomposición de hojarasca entre fragmentos y no fragmentos de bosque altoandino nublado (Sabana de Bogotá, Colombia), Ecotropicos, 15, 185-193, 2003.

Varela, A., Cortés, C., and Cotes, C.: Cambios en edafofauna asociada a descomposición de hojarasca en un bosque nublado, Rev. Colomb. Entomol., 33, 45-53, 2007.

Vásquez, E., Ladd, B., and Borchard, N.: Carbon storage in a highaltitude Polylepis woodland in the Peruvian Andes, Alp. Bot., 124, 71-75, https://doi.org/10.1007/s00035-014-0126-y, 2014.

Veen, G. F., Freschet, G. T., Ordonez, A., and Wardle, D. A.: Litter quality and environmental controls of home-field advantage effects on litter decomposition, Oikos, 124, 187-195, https://doi.org/10.1111/oik.01374, 2015.

Velescu, A., Valarezo, C., and Wilcke, W.: Response of Dissolved Carbon and Nitrogen Concentrations to Moderate Nutrient Additions in a Tropical Montane Forest of South Ecuador, Front. Earth Sci., 4, 58, https://doi.org/10.3389/feart.2016.00058, 2016.

Vivanco, L. and Austin, A. T.: Tree species identity alters forest litter decomposition through long-term plant and soil interaction in Patagonia, Argentina, J. Ecol., 96, 727-736, https://doi.org/10.1111/j.1365-2745.2008.01393.x, 2008.

Wall, D. H., Bradford, M. A., St John, M. G., Trofymow, J. A., Behan-Pelletier, V., Bignell de, Dangerfield, J. M., Parton, W. J., Rusek, J., Voigt, W., Wolters, V., Gardel, H. Z., Ayuke, F. O., Bashford, R., Beljakova, O. I., Bohlen, P. J., Brauman, A, Flemming, S., Henschel, J. O. H. R., Johnson, D. A. N. L., Jones, T. H., Kovarova, M., Kranabetter, J. M., Kutny, L. E. S., Lin, K. U. O. C., Maryati, M., Masse, D., Pokarzhevskii, A., Rahman, H., Sabará, M. G., Salamon, J. A., Swift, M. J., Varela, A., Vasconcelos, H. L., White, D. O. N., and Zou, X: Global decomposition experiment shows soil animal impacts on decomposition are climate-dependent, Global Change Biol., 14, 2661-2677, https://doi.org/10.1111/j.1365-2486.2008.01672.x, 2008.

Wanyama, I., Pelster, D. E., Butterbach-Bahl, K., Verchot, L. V., Martius, C., and Rufino, M. C.: Soil carbon dioxide and methane fluxes from forests and other land use types in an African tropical montane region, Biogeochemistry, 143, 171190, https://doi.org/10.1007/s10533-019-00555-8, 2019.

Weigelt, A., Mommer, L., Andraczek, K., Iversen, C. M., Bergmann, J., Bruelheide, H., Fan, Y., Freschet, G. T., GuerreroRamírez, N. R., Kattge, J., Kuyper, T. W., Laughlin, D. C., Meier, I. C., van der Plas, F., Poorter, H., Roumet, C., van Ruijven, J., Sabatini, F. M., Semchenko, M., Sweeney, C. J., Valverde-Barrantes, O. J., York, L. M., and McCormack, M. L.: An integrated framework of plant form and function: the belowground perspective, New Phytol., 232, 42-59, https://doi.org/10.1111/nph.17590, 2021.

Werner, F. and Homeier, J.: Is tropical montane forest heterogeneity promoted by a resource-driven feedback cycle? Evidence from nutrient relations, herbivory and litter decomposition along a topographical gradient, Funct. Ecol., 29, 430-440, https://doi.org/10.1111/1365-2435.12351, 2015.

Whitaker, J., Ostle, N., Nottingham, A., Ccahuana, A., Salinas, N., Bardgett, R., Meir, P., and McNamara, N.: Microbial community composition explains soil respiration responses to changing carbon inputs along an Andes-to-Amazon elevation gradient, J. Ecol., 102, 1058-1071, 2014.

Wilcke, W., Yasin, S., Abramowski, U., Valarezo, C., and Zech, W.: Nutrient storage and turnover in organic layers under tropical montane rain forest in Ecuador, Eur. J. Soil Sci., 53, 15-27, https://doi.org/10.1046/j.1365-2389.2002.00411.x, 2002.

Wilcke, W., Hess, T., Bengel, C., Homeier, J., Valarezo, C., and Zech, W.: Coarse woody debris in a montane forest in Ecuador: mass, $\mathrm{C}$ and nutrient stock, and turnover, Forest Ecol. Manage., 205, 139-147, https://doi.org/10.1016/j.foreco.2004.10.044, 2005.

Wilcke, W., Oelmann, Y., Schmitt, A., Valarezo, C., Zech, W., and Homeier, J.: Soil properties and tree growth along an altitudinal transect in Ecuadorian tropical montane forest, J. Soil Sci. Plant Nutr., 171, 220-230, https://doi.org/10.1002/jpln.200625210, 2008.

Wittich, B., Horna, V., Homeier, J., and Leuschner, C.: Altitudinal Change in the Photosynthetic Capacity of Tropical Trees: A Case Study from Ecuador and a Pantropical Literature Analysis, Ecosystems, 15, 958-973, https://doi.org/10.1007/s10021012-9556-9, 2012.

Wolf, K., Veldkamp, E., Homeier, J., and Martinson, G. O.: Nitrogen availability links forest productivity, soil nitrous oxide and nitric oxide fluxes of a tropical montane forest in southern Ecuador, Global Biogeochem., Cy., 25, GB4009, https://doi.org/10.1029/2010GB003876, 2011.

Yepes, A., Herrera, J., Phillips, J., Cabrera, E., Galindo, G., Granados, E., Duque, A., Barbosa, A., Olarte, C., and Cardona, M.: Contribución de los bosques tropicales de montaña en el almacenamiento de carbono en Colombia, Rev. Biol. Trop., 63, 69-82, https://doi.org/10.15517/rbt.v63i1.14679, 2015.

Yepes, A., Sierra, A., Niño, L. M., López, M., Garay, C., Vargas, D., Cabrera, E., and Barbosa, A.: Biomasa y carbono total almacenado en robledales del sur de los Andes Colombianos: aportes para el enfoque REDD+ a escala de proyectos, Rev. Biol. Trop., 64, 399-412, https://doi.org/10.15517/rbt.v64i1.18221, 2016.

Yimer, F., Ledin, S., and Abdelkadir, A.: Soil organic carbon and total nitrogen stocks as affected by topographic aspect and vegetation in the Bale Mountains, Ethiopia, Geoderma, 135, 335-344, https://doi.org/10.1016/j.geoderma.2006.01.005, 2006.

Zach, A., Horna, V., and Leuschner, C.: Elevational change in woody tissue $\mathrm{CO}_{2}$ efflux in a tropical mountain rain forest in southern Ecuador, Tree Physiol., 28, 67-74, https://doi.org/10.1093/treephys/28.1.67, 2008.

Zach, A., Horna, V., Leuschner, C., and Zimmermann, R.: Patterns of wood carbon dioxide efflux across a 2,000-m elevation transect in an Andean moist forest, Oecologia, 162, 127-137, https://doi.org/10.1007/s00442-009-1438-2, 2010.

Zapata-Duque, C. M., Ramírez, J. A., León-Peláez, J. D., and González-Hernández, M. I.: Producción de hojarasca fina en bosques alto andinos de Antioquia, Colombia, Rev. Fac. Nac. Agron. Medellín, 60, 3771-3784, 2007.

Zimmermann, M., Meir, P., Bird, M. I., Malhi, Y., and Ccahuana, A. J. Q.: Climate dependence of heterotrophic soil respiration from a soil-translocation experiment along a $3000 \mathrm{~m}$ tropical forest altitudinal gradient, Eur. J. Soil Sci., 60, 895-906, https://doi.org/10.1111/j.1365-2389.2009.01175.x, 2009a.

Zimmermann, M., Meir, P., Bird, M., Malhi, Y., and Ccahuana, A.: Litter contribution to diurnal and annual soil respiration in a trop- 
ical montane cloud forest, Soil Biol. Biochem., 41, 1338-1340, https://doi.org/10.1016/j.soilbio.2009.02.023, 2009b.

Zimmermann, M., Meir, P., Silman, M. R., Fedders, A., Gibbon, A. Malhi, Y., Urrego, D. H., Busch, M. B., Feelye, K. J., Garcia, K. C., Dargie, G. C., Farfan, W. R., Goetz, B. P., Johnson, W. T., Kline, K. M., Modi, A. T., Rurau, N. M. Q., Staudt, B. T., and Zamora, F.: No Differences in Soil Carbon Stocks Across the Tree Line in the Peruvian Andes, Ecosystems, 13, 62-74, https://doi.org/10.1007/s10021-009-9300-2, 2010a.

Zimmermann, M., Meir, P., Bird, M. I., Malhi, Y., and Ccahuana, A. J. Q.: Temporal variation and climate dependence of soil respiration and its components along a $3000 \mathrm{~m}$ altitudinal tropical forest gradient, Global Biogeochem. Cy., 24, GB4012, https://doi.org/10.1029/2010GB003787, 2010b.
Zimmermann, M., Leifeld, J., Conen, F., Bird, M. I., and Meir, P.: Can composition and physical protection of soil organic matter explain soil respiration temperature sensitivity? Biogeochemistry, 107, 423-436, https://doi.org/10.1007/s10533-010-9562-y, 2012.

Ziter, C., Bennett, E., and Gonzalez, A.: Functional diversity and management mediate aboveground carbon stocks in small forest fragments, Ecosphere, 4, 1-21, 2013.

Zúñiga-Escobar, O., Uribe, V. A., Torres-González, A. M., CueroGuependo, R., and Peña-Óspina, J. A.: Assessment of the impact of anthropic activities on carbon storage in soils of high montane ecosystems in Colombia, Agron. Colomb., 31, 112-119, 2013. 